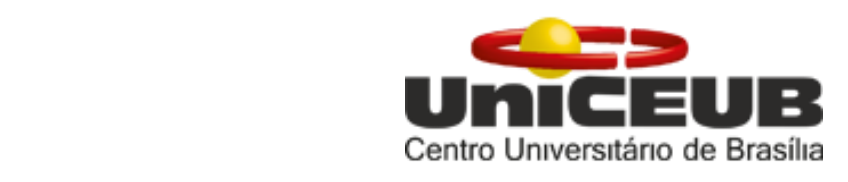

CENTRO UNIVERSITÁRIO DE BRASÍLIA - UniCEUB

PROGRAMA DE INICIAÇÃO CIENTÍFICA

THIAGO TAVARES BORBA DE SOUZA

FELIPE AZEREDO DE CASTRO

\title{
ÍONS MARCADORES DE RÁPIDA IDENTIFICAÇÃO DE DIAGNÓSTICO MOLECULAR EM PLASMA DE PACIENTES COM ZIKA E CHIKUNGUNYA VÍRUS
}

BRASÍLIA 2018 


\section{Uחल \\ Centro Unıversıtárıo de Brasílıa}

\section{THIAGO TAVARES BORBA DE SOUZA FELIPE AZEREDO DE CASTRO}

\section{ÍONS MARCADORES DE RÁPIDA IDENTIFICAÇÃO PARA DIAGNÓSTICO MOLECULAR EM PLASMA DE PACIENTES COM ZIKA E CHIKUNGUNYA VÍRUS}

Relatório final de pesquisa de Iniciação Científica apresentado à Assessoria de PósGraduação e Pesquisa.

Orientação: Profa. Dra. Aline Maria Araújo Martins.

\section{BRASÍLIA}


Dedico esse trabalho a todas as pessoas que tiveram de conviver comigo nos bons e maus momentos de sua feitura. 
Um enorme agradecimento ao apoio de todos que deram suporte ao projeto nas mais variadas formas.

Aos colaboradores, Fábio Santos, Marcos Eberlin e Kelly Magalhães, muito obrigado pelo suporte e pela capacitação.

À minha família, muito obrigado por entenderem o tempo afastado e por me darem todo o suporte no período.

Ao meu marido, muito obrigado pela paciência nos períodos de maior estresse e por me ouvir sempre.

$E$, finalmente, à minha orientadora, Aline Martins, muito obrigado por ser a melhor de todas. Você deixou tudo mais fácil. 


\section{Sumário}

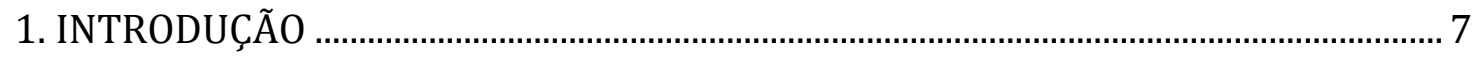

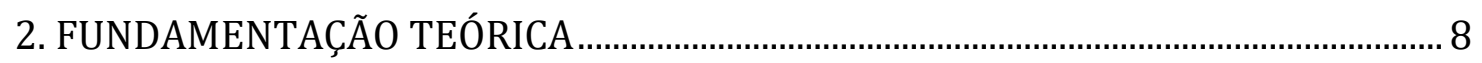

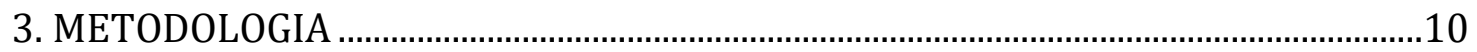

3.1. DEFINIÇÃO DO MÉTODO …………………………………………………………....10

Bligh-Dyer - Matrizes: ............................................................................................12

Bligh-Dyer - Concentrações:...................................................................................12

Bligh-Dyer - Percentual dos feixes de laser:............................................................13

MTBE - Matrizes:………………………………………………………………………14

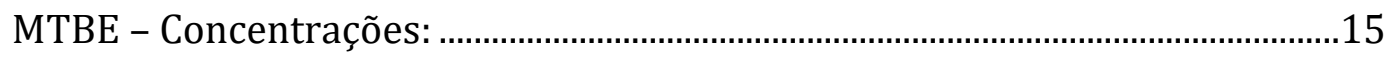

MTBE - Percentual dos feixes de laser: …………………………………………....16

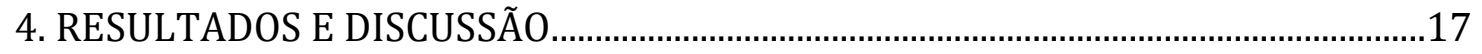

4.1. FASE LIPÍDICA ………………………………………………………………....17

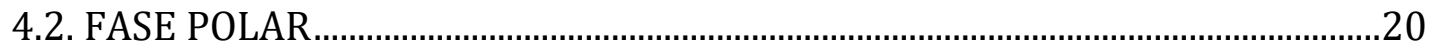

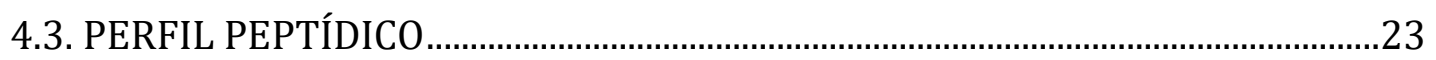

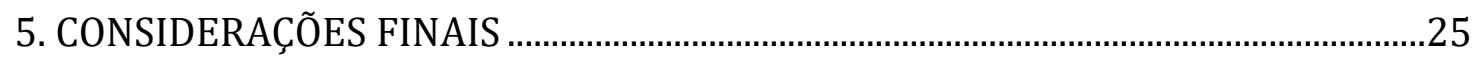

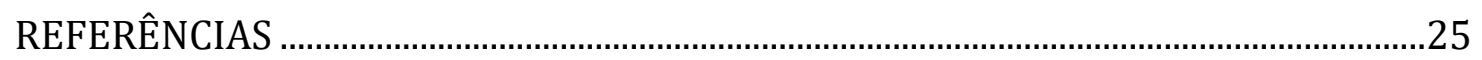

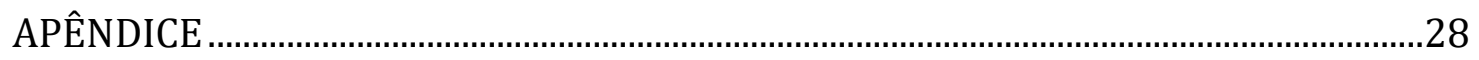

1. GRÁFICOS DOS RESULTADOS DA ANÁLISE DO MÉTODO.......................................28 


\section{ÍONS MARCADORES DE RÁPIDA IDENTIFICAÇÃO PARA DIAGNÓSTICO MOLECULAR EM PLASMA DE PACIENTES COM ZIKA E CHIKUNGUNYA VÍRUS}

\section{RESUMO}

As doenças infecciosas são um grande problema de saúde pública no mundo atualmente, em especial as transmitidas por meio de vetores. O Aedes aegypti é um mosquito capaz de transmitir algumas doenças virais, entre elas a Zika e a Chikungunya, que têm se tornado cada vez mais prevalente, sendo importante alvo de políticas públicas. A confirmação diagnóstica clínica dessas duas doenças é insidiosa, entretanto ambas necessitam de um tratamento precoce para redução de danos subsequentes, principalmente na fase aguda. A espectrometria de massas é uma técnica analítica capaz de fornecer um diagnóstico seguro e rápido ao identificar características moleculares semelhantes em pacientes infectados, que podem ser relacionadas a caracteres específicos da interação com o hospedeiro. Há moléculas presentes nos vírus bem como outras produzidas no momento da invasão ao organismo que podem ser utilizadas para identificar padrões específicos de cada uma das infecções e confirmar o diagnóstico no momento da atividade viral da doença. Deve-se, para isso, identificar moléculas diferenciais em cada uma das doenças virais e utilizá-las para a resposta diagnóstica precoce. O presente trabalho demonstra que, nas infecções pelos vírus Zika e Chikungunya, existem íons marcadores específicos que apresentam diferentes espectros e podem ser utilizados para definição de rápido diagnóstico. Foram usadas quinze amostras de pacientes infectados com Zika, outros quinze com Chikungunya e quinze pacientes hígidos como grupo controle. Para uma melhor eficácia da análise estatística, foram realizados testes para determinar melhores condições para execução dos experimentos da pesquisa avaliando métodos de extração, matriz, concentração de amostra e potência do feixe de laser utilizado. $O$ trabalho pode determinar que na amostra de sangue de pacientes distintos infectados por Zika vírus houve reprodutibilidade no método para o íon marcador $650 \mathrm{~m} / \mathrm{z}$ do espectro, além de importantes relações de proporcionalidade entre outros íons. Da mesma forma, pacientes infectados com Chikungunya vírus apresentaram reprodutibilidade do íon marcador 633 $\mathrm{m} / \mathrm{z}$ da mesma relação. Além desses, foram observadas as porções polares e os peptídeos com bons resultados de íons marcadores nas bandas 567 e 672 o m/z para a Chikungunya. Foram analisados pacientes coinfectados para observação de reprodutibilidade de fingerprint por esta técnica. Conclui-se, portanto, que há uma especificidade apresentada por esses íons referentes a diferentes moléculas que possibilitam identificar de maneira rápida o fingerprint metabólico destas doenças. Essa utilização de biomarcadores para rápido diagnóstico molecular de arboviroses representa uma das melhores alternativas para o futuro de seu diagnóstico.

Palavras-Chave: Zika. Chikungunya. Espectrometria de massas. Íon marcador. Fingerprint metabólico. Diagnóstico molecular. 


\section{INTRODUÇÃO}

As doenças infecciosas apresentam alto potencial de transmissibilidade e seu impacto está relacionado às interações patógeno vs homem, patógeno vs ambiente, homem vs ambiente (FAUCI; MORENS, 2012). No Brasil, além dos surtos de dengue terem aumentado na última década, tem se notificado a emergência de outras arboviroses, como Zika e Chikungunya, ambas causadas por mosquitos do gênero Aedes, principalmente o Aedes aegypti.

O Zika vírus (ZKV), da família Flaviviridae e gênero Flavivirus, foi introduzido recentemente nas Américas sendo notificada a ocorrência no Brasil em 2015. Os primeiros surtos foram detectados no Nordeste, principalmente no estado de Pernambuco, porém em poucos meses o surto se disseminou por todas as regiões do país causando uma epidemia e se constituindo em um problema de saúde pública nacional (OLIVEIRA e VASCONCELOS, 2016).

O Chikungunya (CHIKV), um vírus pertencente à família Togaviridae e ao gênero Alphavirus, também tem incidência crescente no território brasileiro. Os principais sintomas dessa infecção são forte artralgia, febre alta, dores de cabeça, náusea e vômito (KUCHARZ; CEBULA-BYRSKA, 2012). O primeiro caso de transmissão autóctone de CHIKV nas Américas foi registrado em 2013 na região do Caribe (BORTEL, 2014). Um ano depois, esta epidemia já havia se espalhado por outros países da América do Sul, como Guiana Francesa, Venezuela, Colômbia, Suriname, Paraguai e Brasil (CDC, 2014). Atualmente, os estados de Pernambuco, Alagoas, Sergipe, Tocantins, São Paulo e Bahia apresentam os maiores números de casos de CHIKV notificados no país (MINISTÉRIO DA SAÚDE, 2016).

A identificação rápida entre vírus pode ser bastante difícil do ponto de vista proteico devido à sua semelhança natural, mesmo com uma técnica específica como a espectrometria de massas. No entanto, os arbovírus possuem um envelope lipídico que fornece grande substrato de estudo e levanta a possibilidade de se encontrar marcadores moleculares específicos em diferentes vírus, como o CHIKV e o $\mathrm{ZKV}$, para que se desenvolvam técnicas de diagnóstico rápido, o que poderia mudar a velocidade na tomada de decisão das condutas médicas e resultar em menores consequências a curto e médio prazo. O presente trabalho objetiva, portanto, identificar íons marcadores 
moleculares, em especial os lipídicos, nos vírus da Zika e Chikungunya para possibilitar diagnósticos moleculares que identifiquem distintamente as duas doenças.

\section{FUNDAMENTAÇÃO TEÓRICA}

Os vírus da Zika e Chikungunya promovem infecções que, em sua natureza, são simples, mas podem gerar sinais, sintomas e sequelas que são relevantes à saúde de forma individual e coletiva. A introdução desses vírus em novos espaços, como a América Latina e o Caribe, associada a combinações ambientais, abundância do vetor, fatores socioeconômicos locais e restrito conhecimento acerca da disseminação viral podem resultar em problemas de saúde pública de longo prazo (COLÓN-GONZÁLEZ et al, 2017).

Acredita-se que a origem da infecção pelo CHIKV tenha se dado na Oceania. No entanto, a disseminação no continente africano já é bem estabelecida e estudos mostram que nessa região a infecção em primatas pode ser importante para a manutenção do ciclo viral. Vários macacos permanecem infectados e podem servir de reservatório e, mais raramente, ocasionar transmissão interespecífica direta, situações que podem ocorrer com a introdução do vírus em novos ambientes (EASTWOOD et al, 2017).

Sabe-se que a introdução de novos microrganismos em determinados ambientes pode ofertar riscos. É necessário, portanto, refinar o acesso e a qualidade no atendimento de saúde pública. Estudos apontam que o atendimento em saúde deve reforçar assuntos como a proteção contra o vetor e utilização de métodos contraceptivos em locais de grande incidência, em especial do ZKV. Tais orientações podem levantar questões éticas sobre planejamento familiar e intervenções na gestação e apontam forte necessidade de mais estudos sobre o assunto (TAMBO et al, 2017).

A forma de transmissão simples e o diagnóstico clínico limitado pela semelhança entre as doenças dificultam as intervenções e acentuam o risco à saúde pública. O mesmo mosquito transmissor, o Aedes aegypti, é capaz de disseminar as duas doenças com maior contenção biológica na saliva para o CHIKV e menor para o ZKV, facilitando ainda mais sua disseminação (GÖERTZ, 2017). Este comportamento leva a problemas maiores de disseminação, já que há detecção do ZKV em secreção vaginal acima de 14 dias e em eritrócitos acima de 81 dias após primo-infecção (MURRAY et al, 2017). 
Toda essa situação impôs a tentativa de busca por novos critérios de diagnóstico clínico, principalmente para gestantes e ZKV e idosos e CHIKV, com resultados na literatura com sensibilidade e especificidade relativamente baixas, o que leva à busca de melhores alternativas (GODAERT et al, 2017). A literatura aponta que coinfecções podem favorecer a velocidade de replicação de alguns vírus como o Chikungunya (SILVA et al, 2017), o que torna mais necessária a necessidade de diagnósticos rápidos para determinação da conduta clínica a ser estabelecida.

Ambas as doenças possuem sérias consequências a médio e longo prazo. Estudos apontam que a infecção pelo ZKV em recém-nascidos pode resultar em microcefalia, perda de massa cefálica com calcificações, pigmentação de retina e hipertonia precoce com envolvimento extrapiramidal (MOORE et al, 2017), além de permitir reação imunológica cruzada e favorecer o desenvolvimento da síndrome de Guillain-Barré, doença neurológica periférica, com acometimento ascendente e que pode comprometer vias respiratórias (MALTA et al, 2017).

O CHIKV é capaz de deixar sequelas musculares caracterizadas por dor muscular espontânea incapacitante por até três anos após a infecção inicial. Quanto mais tarde são realizadas as intervenções clínicas para a doença, maior a tendência estatística das complicações a médio prazo permanecerem. Estudos mostram que essa situação de incapacitação força à busca por rápidos diagnósticos por meios não clínicos que ajudem no monitoramento de respostas mais rápidas (GIRY et al, 2017).

A partir dessa necessidade, o diagnóstico laboratorial foi empregado, mas com várias limitações. Seu resultado não apresenta possibilidade de confirmação nos primeiros dias de infecção devido ao próprio processamento imunológico do organismo humano e as condutas médicas ainda são baseadas no diagnóstico clínico (WOROBEY, 2017). Como tentativa de ultrapassar essa limitação, surgiram os estudos moleculares vírus das arboviroses, principalmente quanto à interação vírus-hospedeiro.

A espectrometria de massas pode demonstrar ainda eventos mais específicos como a interação molecular entre duas estruturas e sua resposta metabólica (GAO; CAZARES e FISH, 2017). Estudos apontam que a proteômica e, em outra linha de estudo, a transcriptômica, são capazes de determinar moléculas muito específicas e fornecer resultados com alta especificidade (KAN et al, 2017). Contudo, a semelhança entre a carga proteica de vírus com proximidade filogenética dificulta os estudos e o achado de um marcador proteico específico. 
Como alternativa, a lipidômica é uma opção que pode ser de grande importância. Estudos apontam que sua especificidade é grande a ponto de diferenciar doenças semelhantes em um mesmo tecido corporal como descrito por Passos-Castilho et al (2015). O uso dessa técnica torna possível a identificação de alvos moleculares em tecidos orgânicos, já que as respostas celulares à presença viral podem provocar o surgimento de metabólitos de origem lipídica (CLAUS e LIEBERT, 2014).

\section{METODOLOGIA}

Em um microtubo, $200 \mu \mathrm{L}$ do plasma foram ressuspendidos em aproximadamente $150 \mu \mathrm{L}$ de água MilliQ. A esta suspensão foram adicionados $190 \mu \mathrm{L}$ de clorofórmio (grau HPLC) e $375 \mu \mathrm{L}$ de metanol (grau HPLC). Após 2 minutos no vórtex foram adicionados 187,5 $\mu \mathrm{L}$ de clorofórmio (grau HPLC) e $150 \mu \mathrm{L}$ de água MilliQ. A mistura bifásica foi coletada separadamente. A fase inferior, apolar e contendo lipídeos em solução de clorofórmio, foi transferida para outro microtubo e concentrada para eliminar o solvente (procedimento adaptado de Bligh \& Dyer, 1959). A fração metabólica, rica em metabólitos polares, foi coletada. Ambos os extratos foram armazenados $\mathrm{a}-20^{\circ} \mathrm{C}$. O extrato apolar foi redissolvido em metanol/clorofórmio 2:1 no momento da análise. Para o preparo das placas de MALDI, volumes de $1 \mu \mathrm{L}$ da solução do extrato foram depositados, em triplicata, em poços da placa de MALDI, seguida de secagem em temperatura ambiente. Também foram utilizadas a matriz de DHB e o feixe de laser com potencial de $60 \%$ do total.

\subsection{DEFINIÇÃO DO MÉTODO}

Inicialmente, foram realizadas avaliações para o refinamento do método e para estabelecer as condições ótimas de execução. O equipamento a ser utilizado MALDI/TOF MS - permite variações em seus parâmetros de uso como o feixe de laser, a concentração de amostra utilizada e a matriz agregada à amostra. A definição dos melhores parâmetros é fundamental para o melhor resultado alcançado e foi realizada no 
Laboratório Thomson de Espectrometria de Massa, da Universidade de Campinas UNICAMP, de 5 a 10 de fevereiro de 2018.

Além das variáveis do MALDI/TOF MS, também foi verificado outro método de extração lipídica baseado na utilização de metil-terc-butil-eter (MTBE). Para tanto, foram adicionados $225 \mu \mathrm{L}$ de $\mathrm{MeOH}$ frio a $50 \mu \mathrm{L}$ de amostra, misturando-os por $10 \mathrm{seg}$. Depois, foram adicionados $750 \mu \mathrm{L}$ de MTBE, também misturado por mais $10 \mathrm{seg}$. O resultado foi levado ao vórtex por $10 \mathrm{~min}$ e, logo depois, foram adicionados $188 \mu \mathrm{L}$ de água milliQ, com nova mistura de $20 \mathrm{seg}$. A solução foi centrifugada a $14000 \mathrm{rpm}$ por 10 min a $4^{\circ} \mathrm{C}$. Após centrifugação, foi realizada coleta da fase orgânica (superior) que foi seca com speed-vac por $1 \mathrm{~h}$ e $30 \mathrm{~min}$. O material obtido foi ressuspenso em $100 \mu \mathrm{L}$ de $\mathrm{MeOH}$ e levado ao vórtex por mais 5 min. Logo após, foi novamente centrifugado a $14000 \mathrm{rpm}$ por $5 \mathrm{~min}$ a $4^{\circ} \mathrm{C}$.

Para a análise do método, foram comparadas quatro matrizes diferentes: o ácido dihidroxibenzoico (DHB), a 9-aminoacridina (AMC), o ácido $\alpha$-ciano-hidroxicinâmico (CIANO) e o ácido transferrúlico (ATF). Também foram comparadas as concentrações $(0,5 \mu \mathrm{L} ; 1 \mu \mathrm{L} ; 1,5 \mu \mathrm{L})$ e a intensidade do feixe de laser do aparelho (60\% e $70 \%)$. Todas as amostras foram comparadas em triplicata com igual número de disparos (10 em cada amostra) para comparação entre os espectros (Apêndice 1).

Foram realizadas avaliações estatísticas para determinar a margem de segurança para a análise dos dados encontrados, pelo software Metaboanalyst. Foram utilizados relação massa/carga com erro de 0.4 , desvio-padrão relativo não paramétrico, escala de Pareto e margem de erro de $0.5 \%$. Para os métodos de extração Bligh-Dyer e MTBE, foram comparadas as variâncias das matrizes utilizadas no MALDI, das concentrações aplicadas e do percentual de feixes de laser utilizados com os seguintes resultados, para só então ser escolhido método definitivo, como demonstrado a seguir. 
Bligh-Dyer - Matrizes:

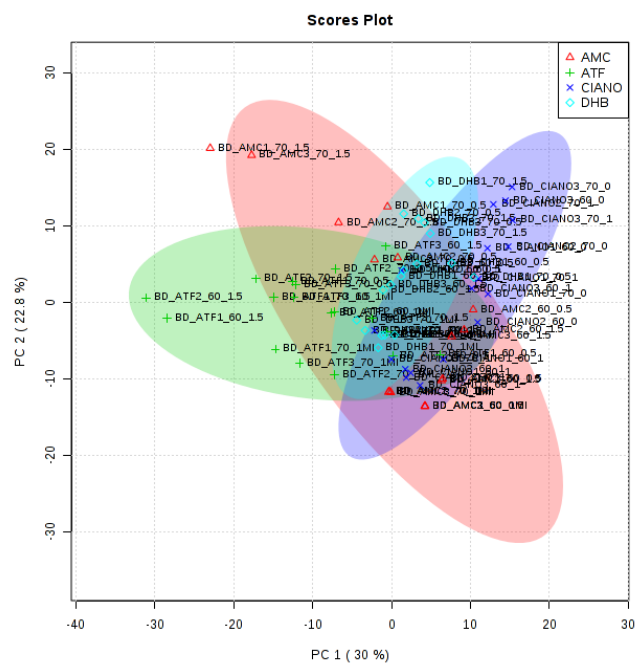

Bligh-Dyer - Concentrações:
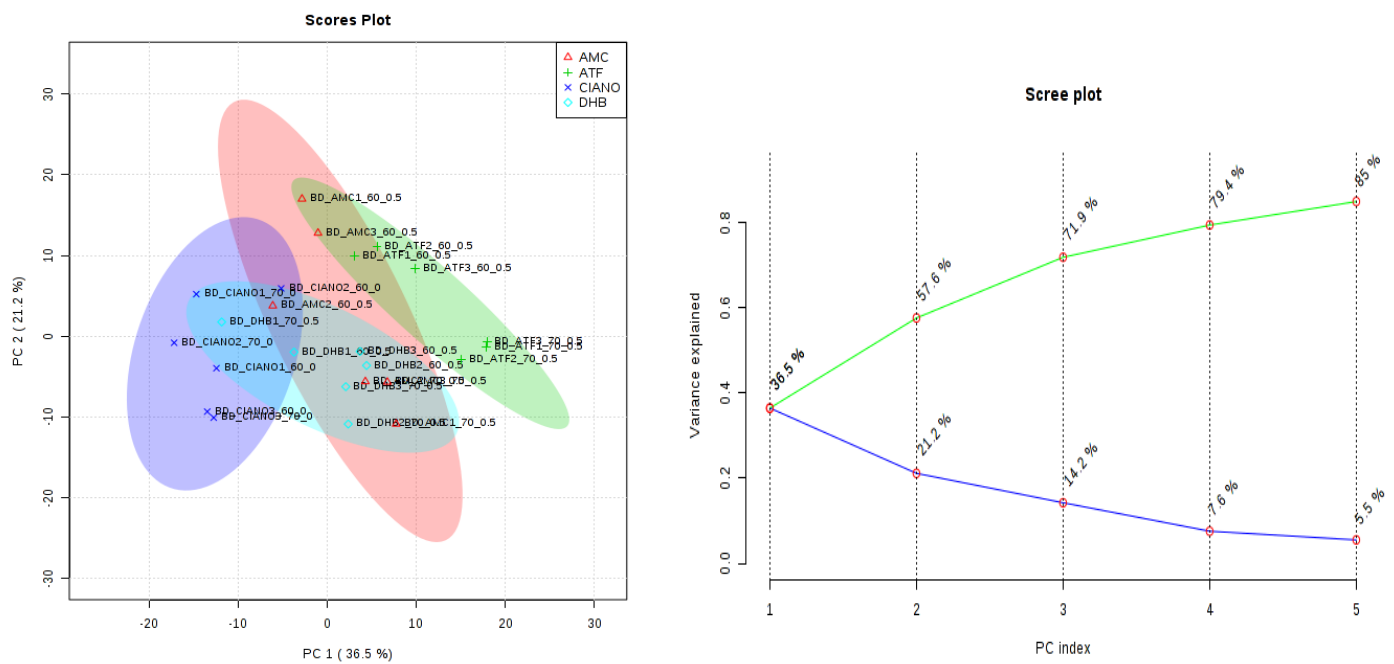

- $1 \mu \mathrm{L}:$
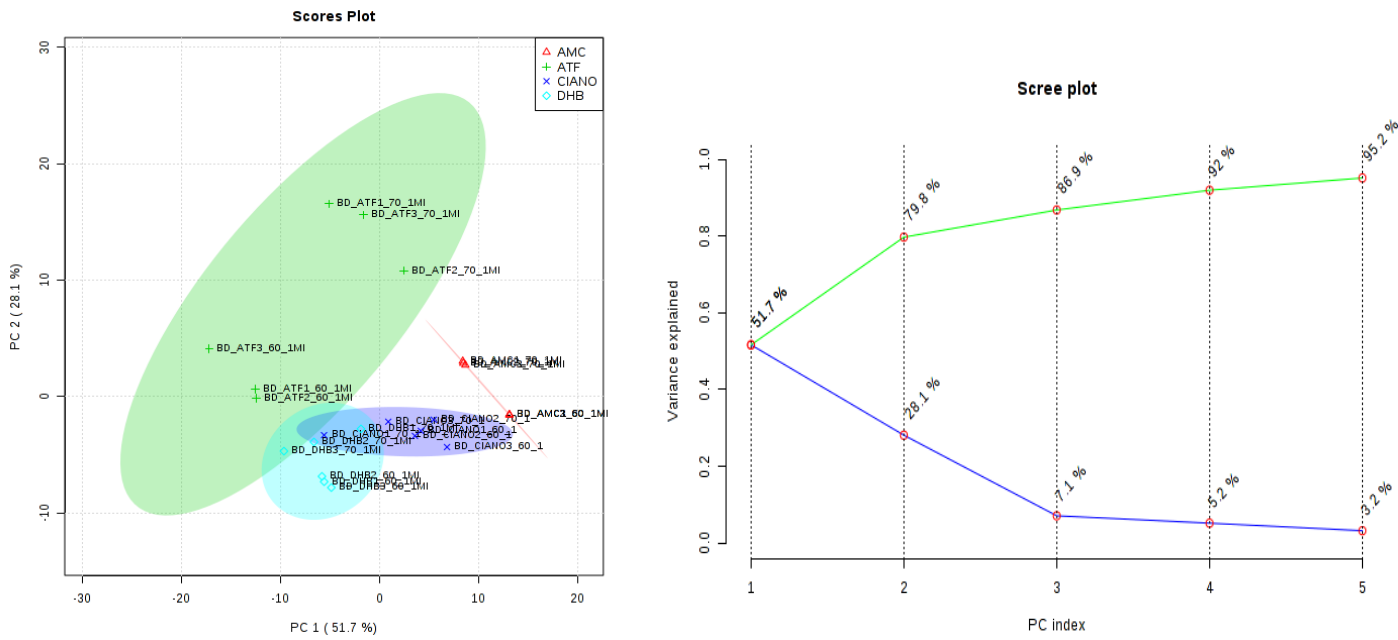
- $1.5 \mu \mathrm{L}$ :
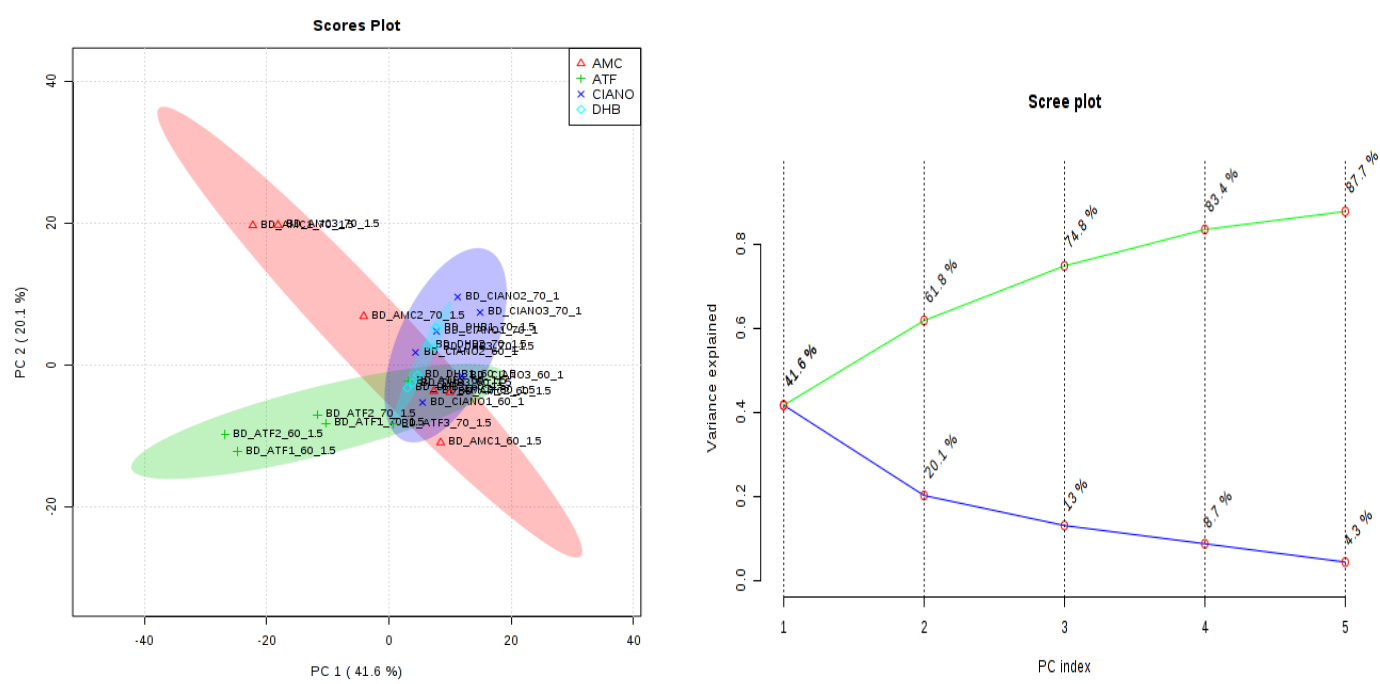

Bligh-Dyer - Percentual dos feixes de laser:

- Aplicação de 60\%:
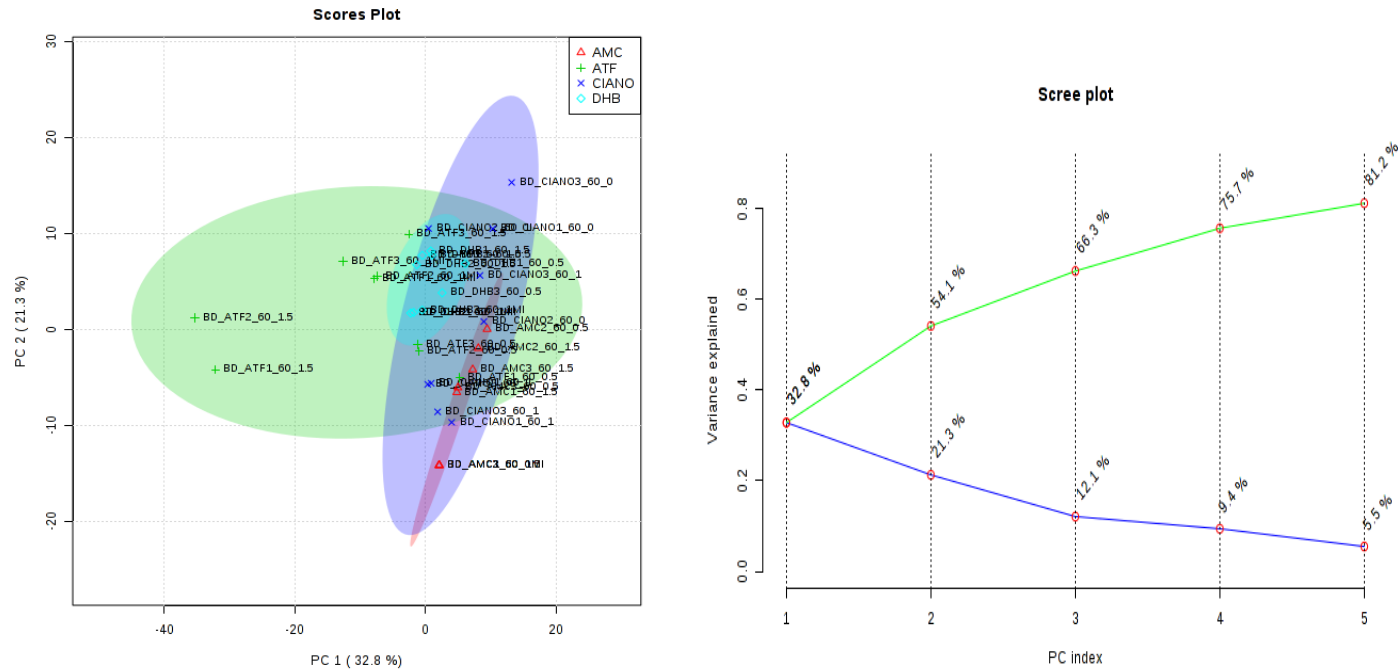
- Aplicação de $70 \%$ :
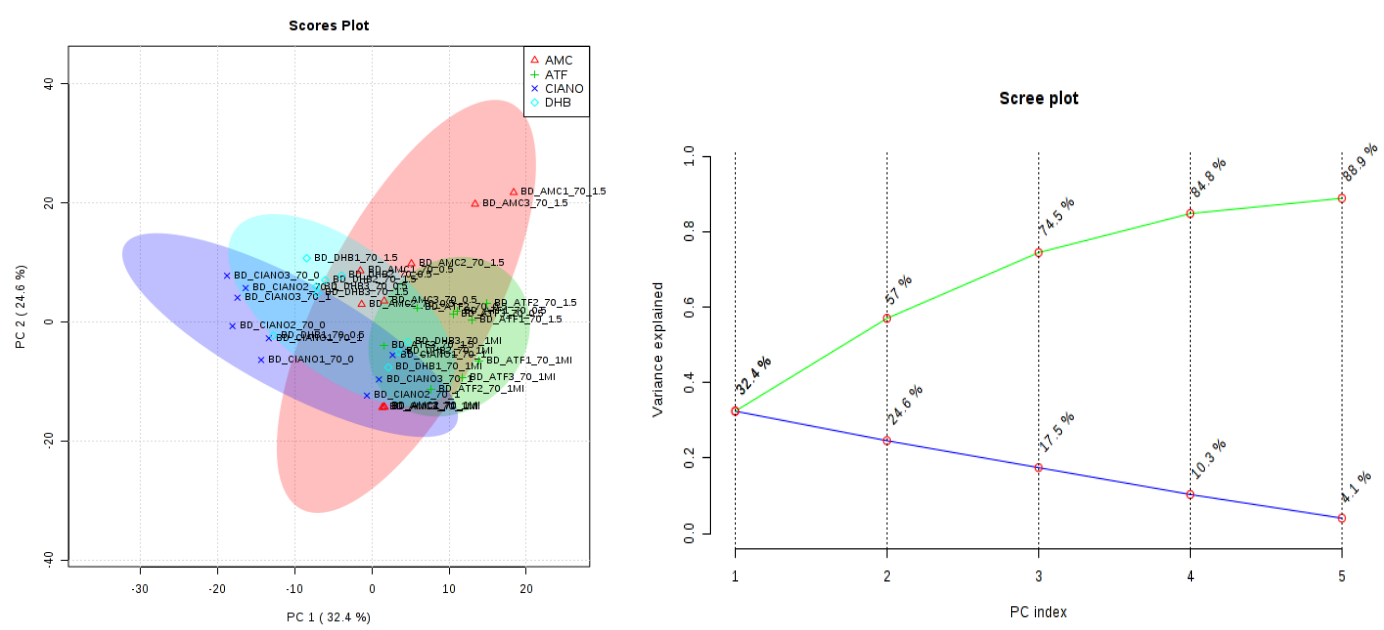

MTBE - Matrizes:
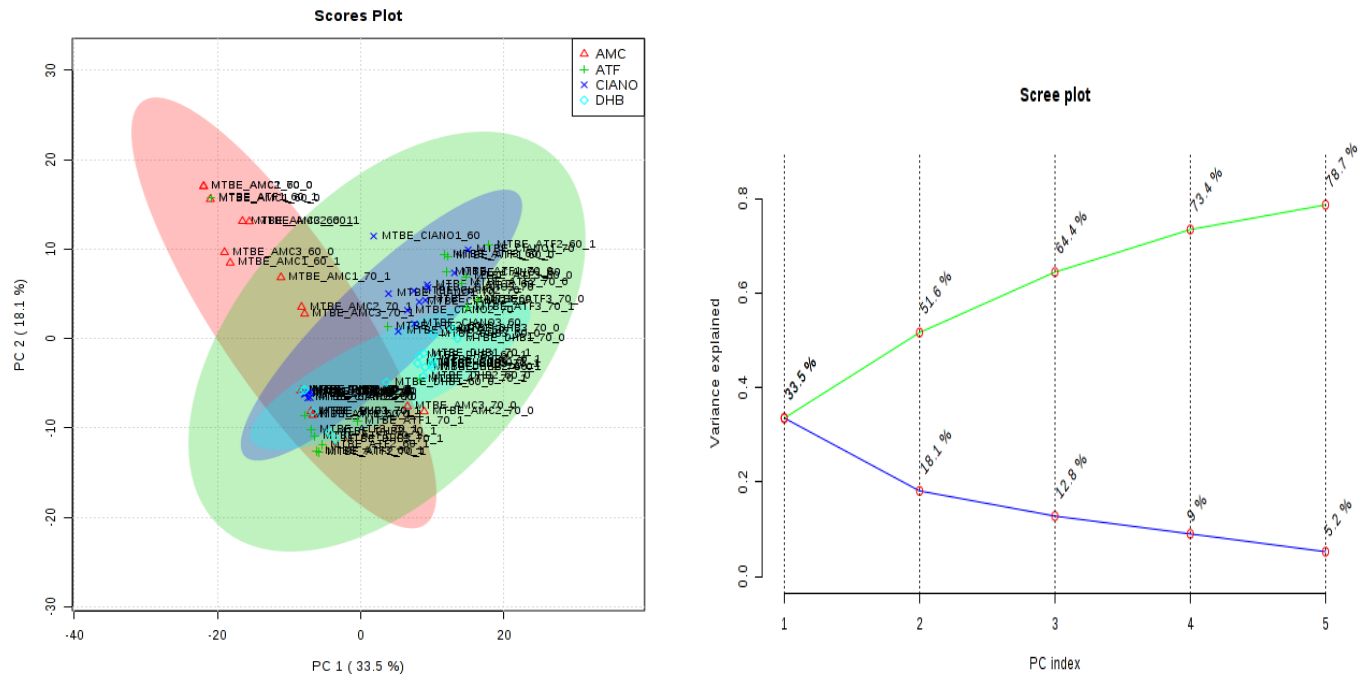
MTBE - Concentrações:

- $0.5 \mu \mathrm{L}$ :
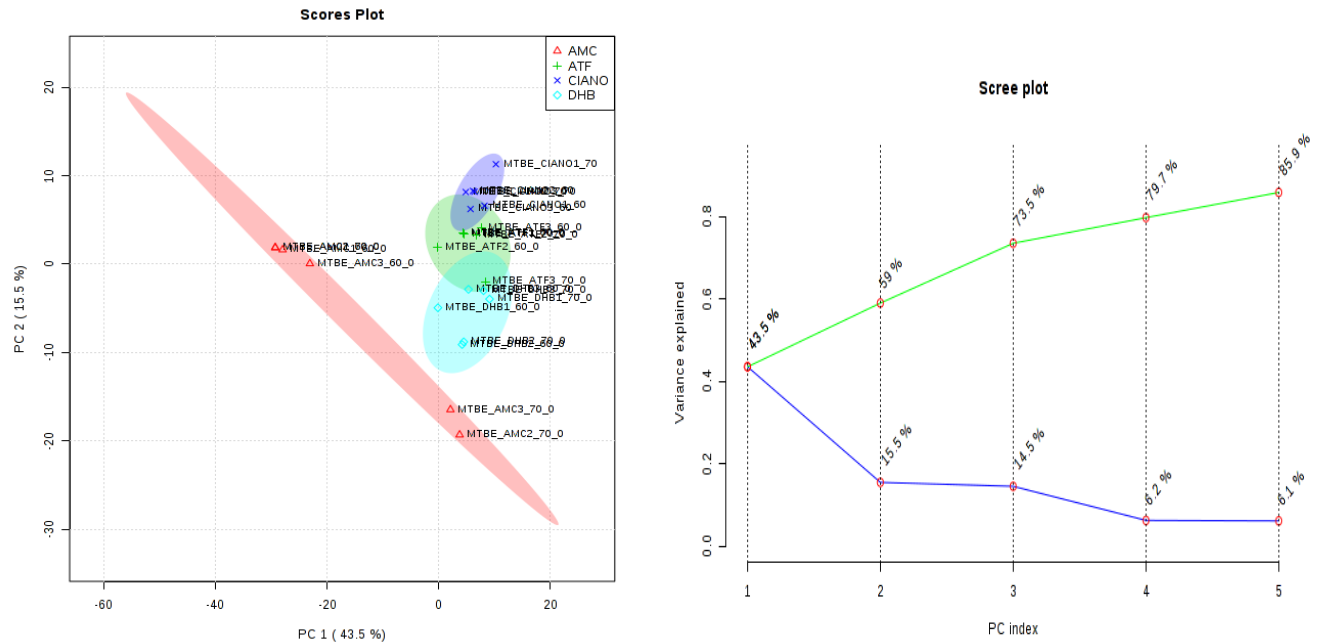

- $1 \mu \mathrm{L}$ :
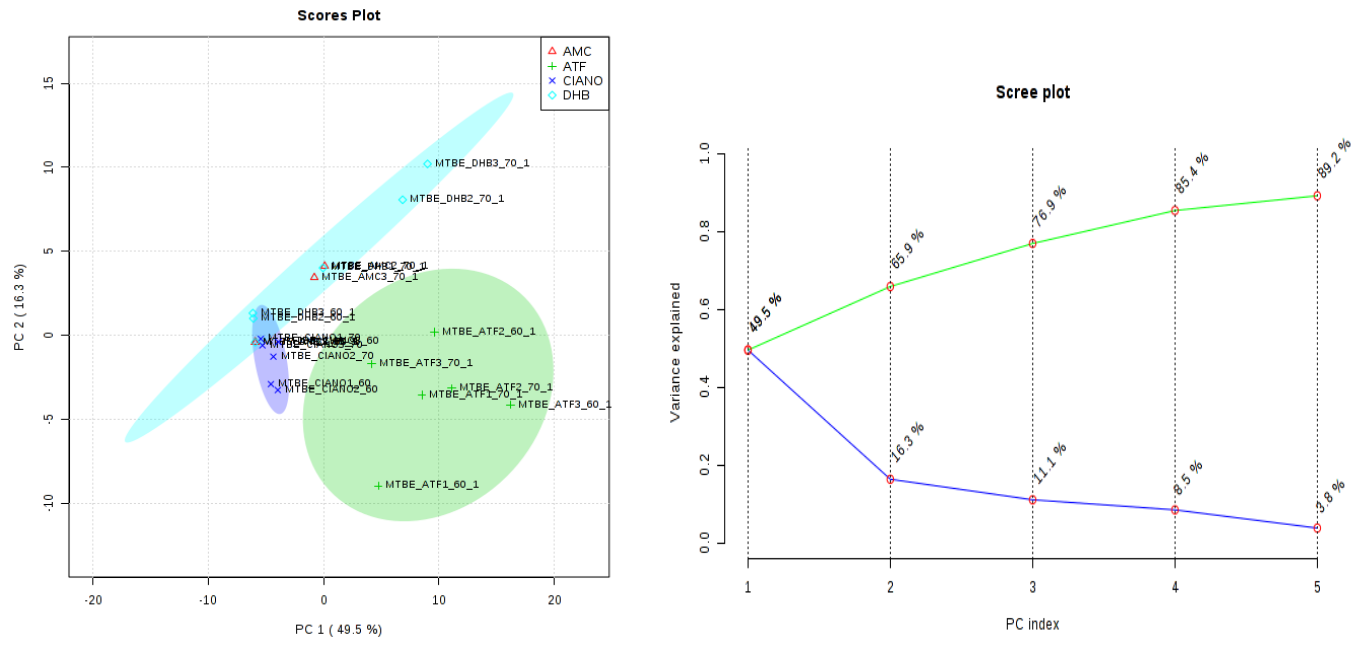

- $\quad 1.5 \mu \mathrm{L}$ :
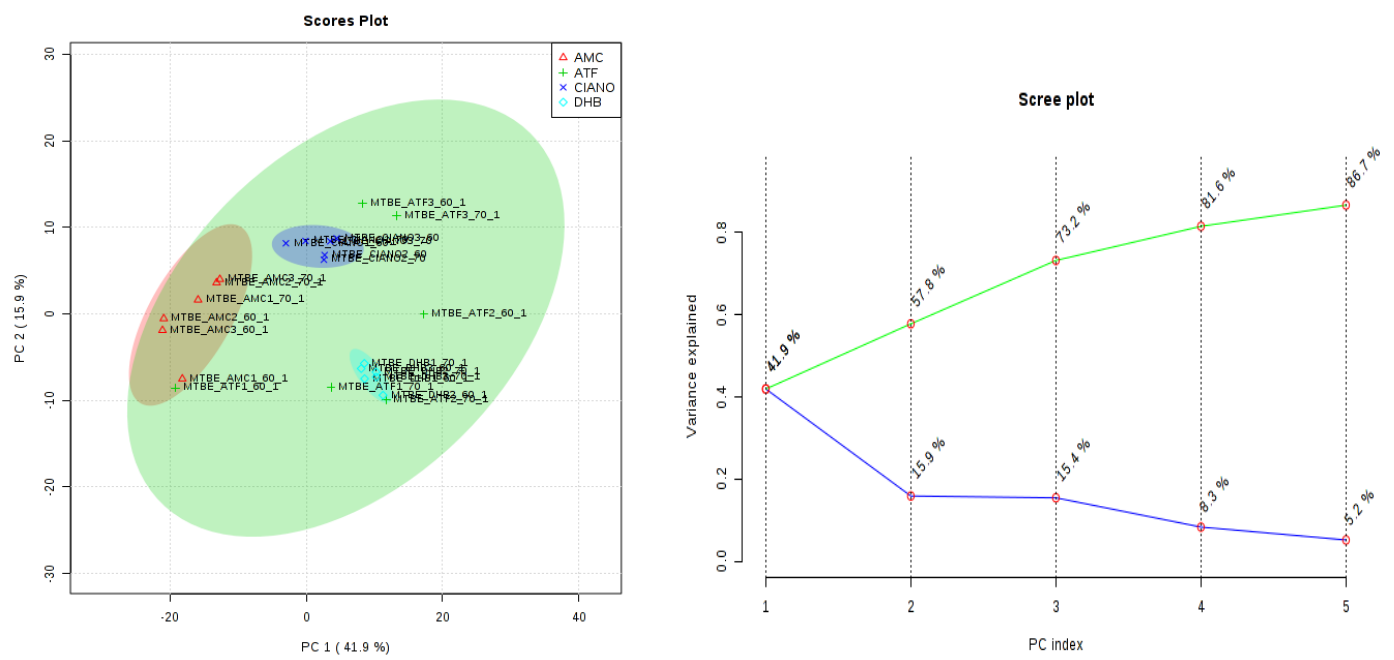
MTBE - Percentual dos feixes de laser:

- Aplicação de 60\%:
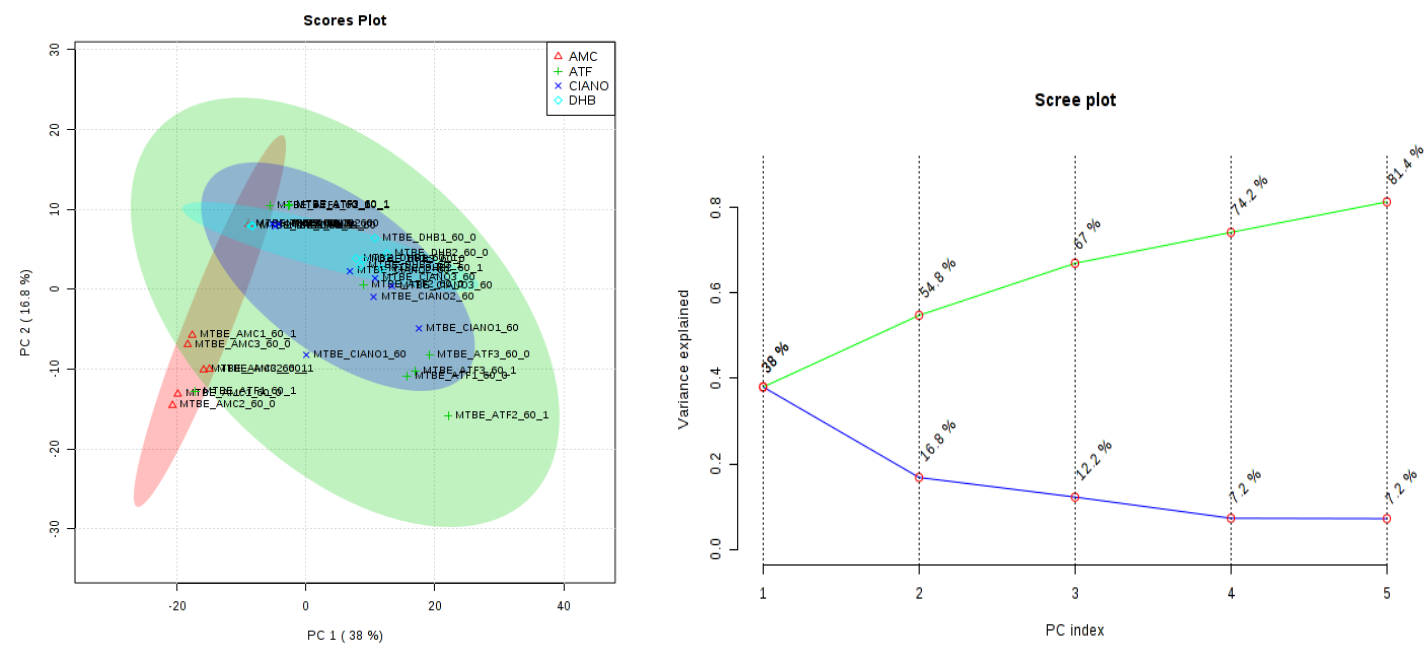

- Aplicação de 70\%:
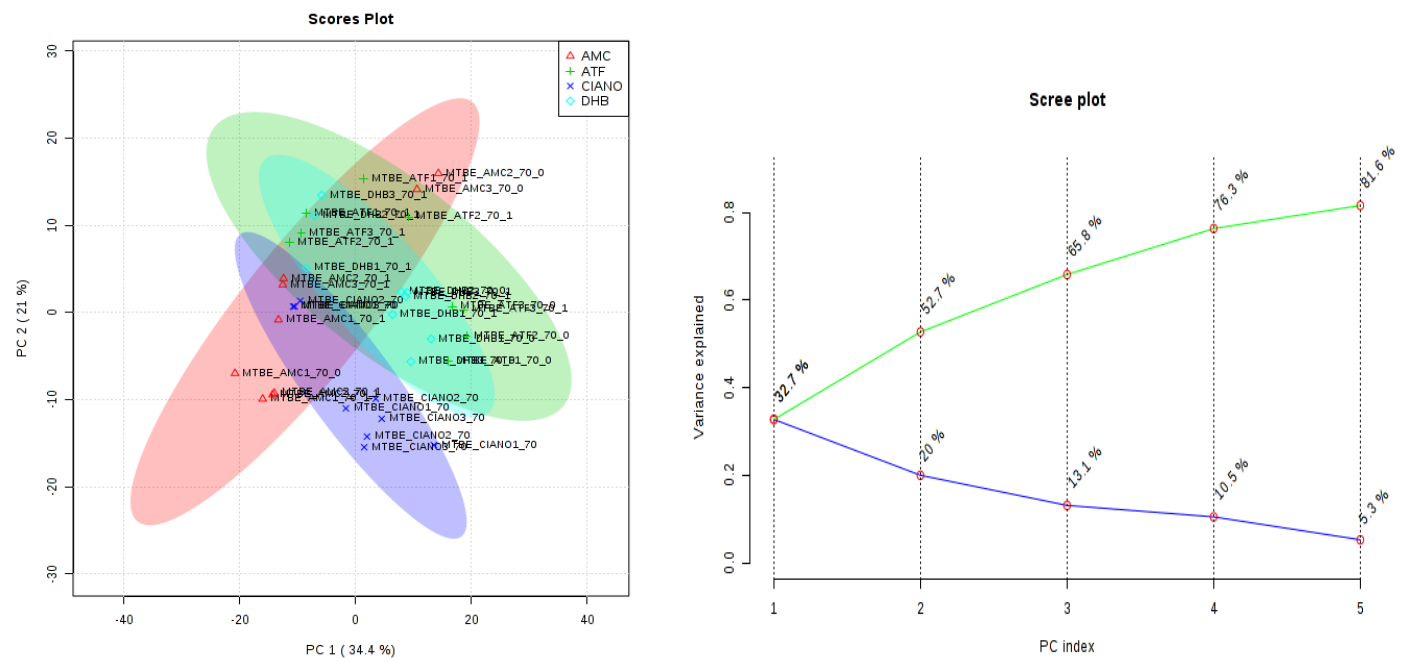

Após análise estatística cuidadosa, foi observado que as melhores condições para a execução dos experimentos tratam-se da utilização de métodos de extração Bligh-Dyer, utilizando-se a matriz DHB, a concentração da amostra de $1 \mu \mathrm{L}$ e aplicando-se o feixe de laser a $60 \%$ do potencial total. 


\section{RESULTADOS E DISCUSSÃO}

\subsection{FASE LIPÍDICA}

Inicialmente, é interessante destacar as semelhanças entre os componentes encontrados na leitura do MALDI/TOF MS, já que os objetos da observação se tratam de vírus com ciclos de vida e interações com o hospedeiro que compartilham muitas homologias metabólicas. As relações $\mathrm{m} / \mathrm{z}$ na leitura do espectrômetro entre as faixas em torno de 703 e 832 apresentam-se igualmente nas duas espécies e com intensidade semelhante em ambas. Essa provavelmente trata-se da maior parte do envelope lipídico compartilhado por ambas as espécies. Também é observado que após a faixa de 832 não há mais expressão de moléculas na fase lipídica, tornando esse fato uma chave de investigação na comparação com outras arboviroses.

Na apresentação do CHIKV (Figura 1), foi observado que o íon 633 apresentase com intensidade em torno de $1.10^{4}$ e não aparece na leitura do ZIKV. Além disso, existe uma relação entre os íons de marcação 518 e 546 em que ambos sempre aparecem em uma proporção de 2:1, situação não observada na outra resposta metabólica viral. A literatura demonstra que esses marcadores moleculares, quando associados à resposta de um determinado espécime, podem ser utilizados para identificação de suas respectivas estruturas orgânicas (KLITZKE, 2012). Dessa forma, as características próprias definidas neste trabalho à leitura do CHIKV na espectrometria de massas podem levar à rápida identificação do vírus.

A leitura do ZIKV (Figura 2) apresentou dois íons marcadores nas faixas em torno de 650 e $678 \mathrm{~m} / \mathrm{z}$ com intensidade média de $4.10^{4}$ e $1.10^{4}$, respectivamente. O referido achado não foi detectado na leitura do CHIKV e pode ser usado para identificação da infecção da Zika. Além do íon, foi observada também a relação entre os íons nas bandas 524 e $548 \mathrm{~m} / \mathrm{z}$ na proporção média de 3:1 que se mantém nas leituras e também pode ser utilizada para identificação, pois não existe na leitura da Chikungunya de forma a se observar nos gráficos do perfil lipídico comparativo (Figura 3).

\section{PERFIL LIPÍDICO CHIKV}




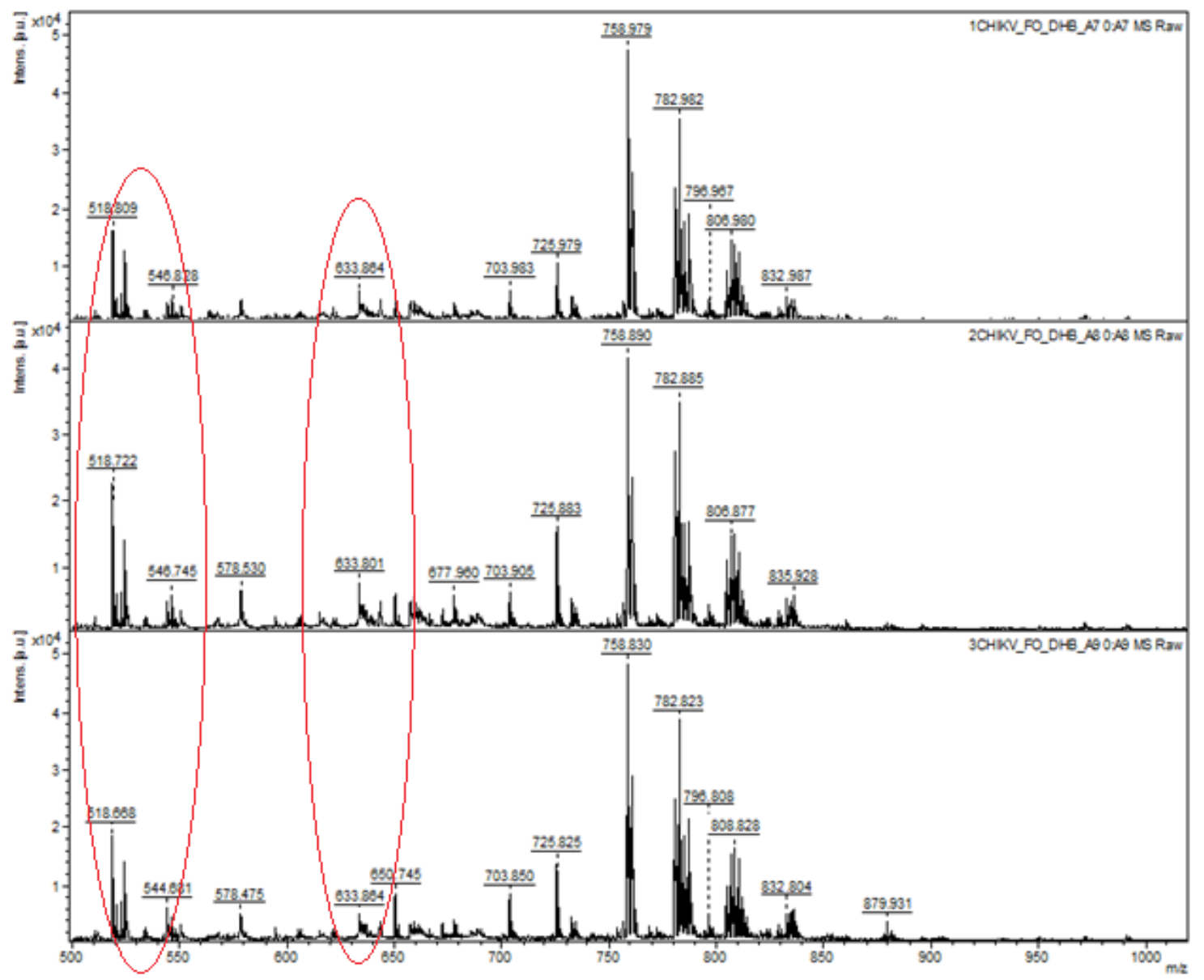

Figura 1 - TIC (total ion current chromatogram) do perfil lipídico do CHIKV. Do lado esquerdo, a proporção de 2:1 observada entre os íons $518 \mathrm{~m} / \mathrm{z}$ e $546 \mathrm{~m} / \mathrm{z}$. Do lado direito, o íon $633 \mathrm{~m} / \mathrm{z}$. 


\section{PERFIL LIPÍDICO ZIKV}

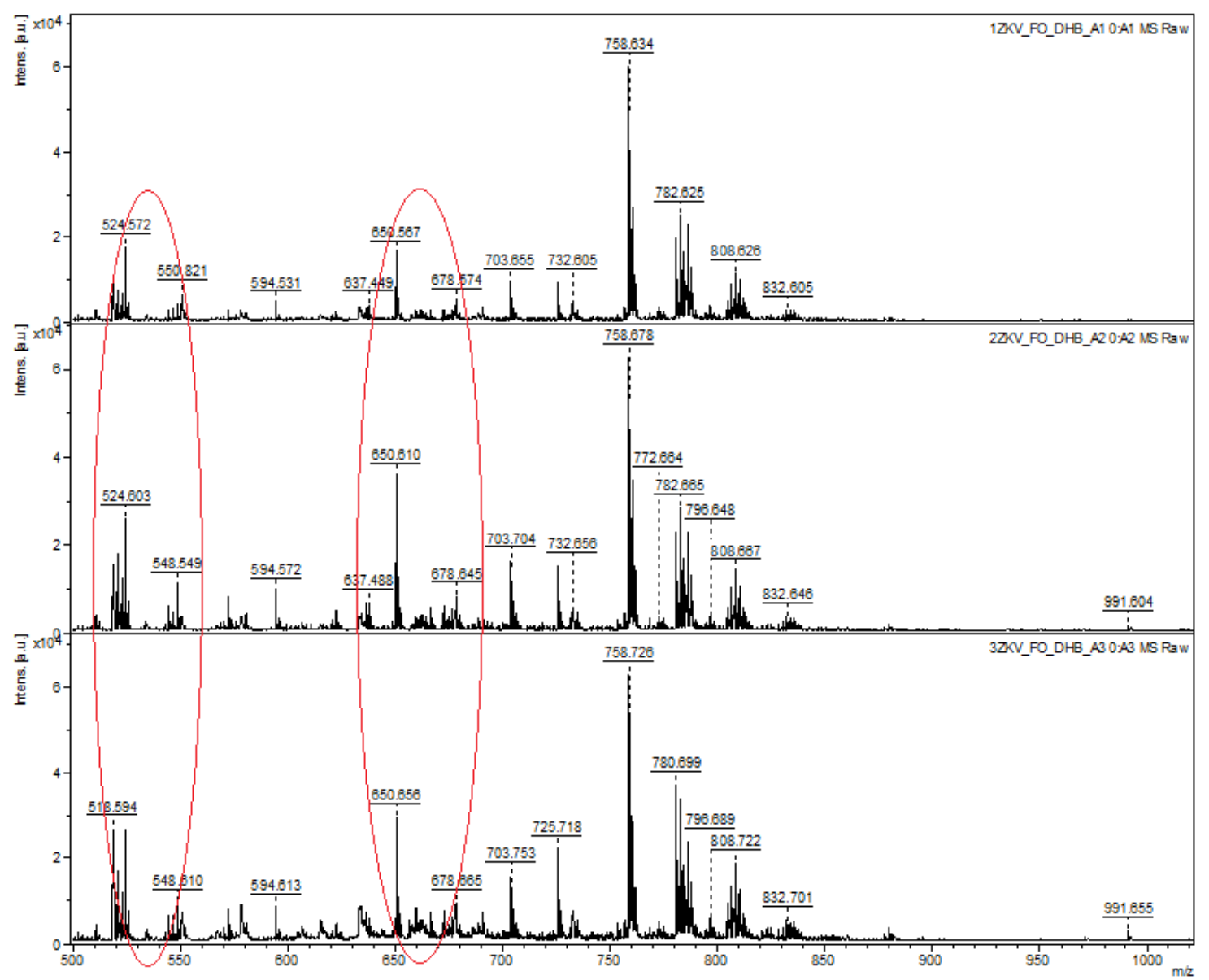

Figura 2 - TIC (total ion current chromatogram) do perfil lipídico do CHIKV. Do lado esquerdo, a proporção de 3:1 observada entre os íons $524 \mathrm{~m} / \mathrm{z}$ e $548 \mathrm{~m} / \mathrm{z}$. Do lado direito, os íons $650 \mathrm{~m} / \mathrm{z}$ e $678 \mathrm{~m} / \mathrm{z}$.

\section{PERFIL LIPÍDICO: COMPARATIVO}

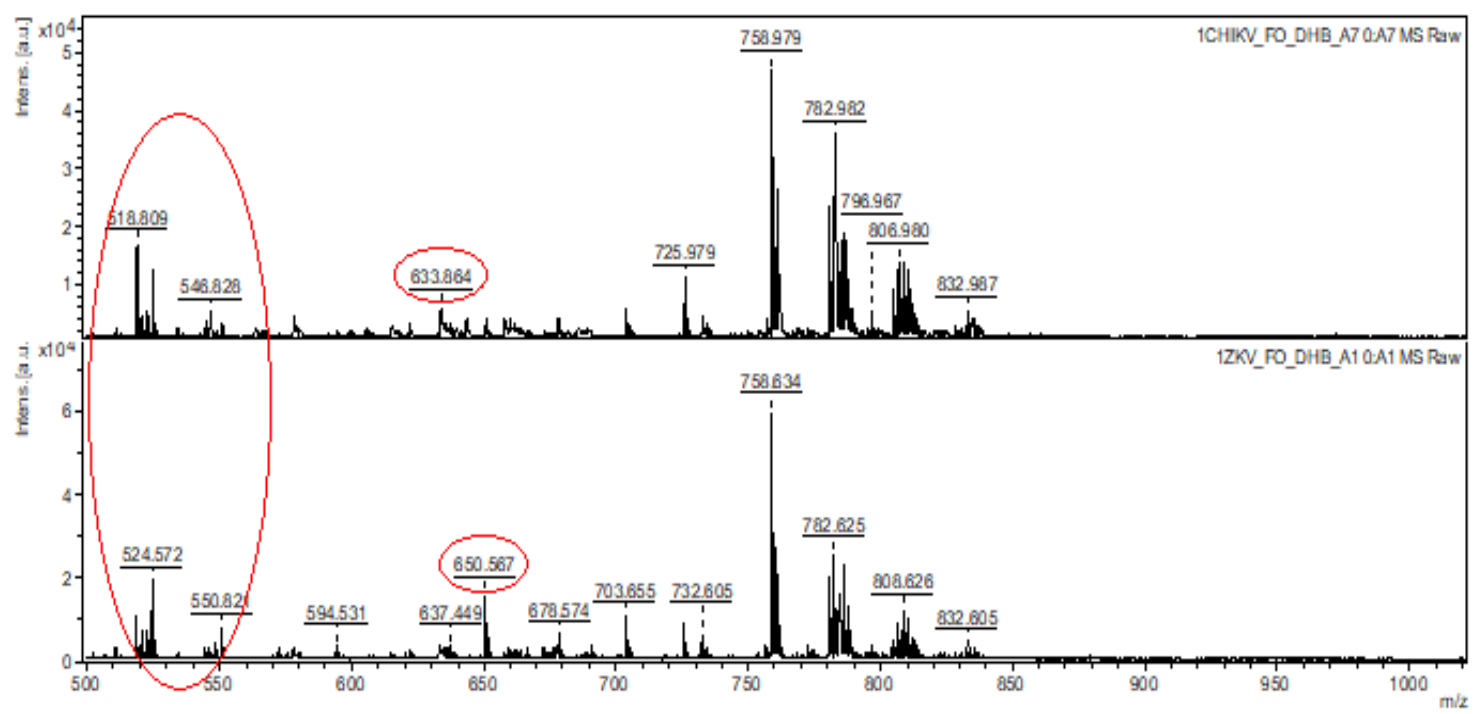

Figura 3 - TIC (total ion current chromatogram) do perfil lipídico comparativo. 


\subsection{FASE POLAR}

A fase polar, predominantemente composta por metabólitos de menor tamanho, provenientes do metabolismo de cada doença específica, apresentou resultados muito característicos. Tanto o ZIKV quanto o CHIKV apresentam duas regiões com várias expressões iônicas comuns. Entre $518 \mathrm{~m} / \mathrm{z}$ e $567 \mathrm{~m} / \mathrm{z}$ com intensidade entre $4.10^{4}$ e $1.10^{4}$ e entre $672 \mathrm{~m} / \mathrm{z}$ e $782 \mathrm{~m} / \mathrm{z}$ com baixas intensidades, porém bastante prevalentes.

A fase polar das amostras do CHIKV (Figura 4) apresentou o íon 537 m/z com uma intensidade de $3 \cdot 10^{4}$. Apesar de ser o mesmo íon observado no ZIKV, a intensidade relativa com que se apresenta é duas vezes maior e pode tornar possível a utilização do íon para identificação. Outros íons se sobressaem com menor intensidade, porém com presença no intervalo no qual o ZIKV não apresenta íons. São eles os íons 638 m/z, 749 $\mathrm{m} / \mathrm{z}$ e $860 \mathrm{~m} / \mathrm{z}$. O mais expressivo íon na fase polar para identificação do CHIKV é o $659 \mathrm{~m} / \mathrm{z}$ que não é observado no ZIKV, possuindo intensidade relativa em torno de $1,5.10^{4}$, bastante expressivo quando comparados com outros.

O ZIKV apresentou em sua fase polar (Figura 5) poucos picos que se apresentam de forma bastante regular. $\mathrm{O}$ íon $537 \mathrm{~m} / \mathrm{z}$ se ioniza de forma constante, com uma intensidade em torno de 1,5.104. Foi observado ainda que os intervalos entre 567-672 $\mathrm{m} / \mathrm{z}$ e $780-966 \mathrm{~m} / \mathrm{z}$ apresentam-se completamente vazios nas diferentes amostras analisadas. Assim, pode-se utilizar como método de identificação a ausência de picos nesses intervalos no lugar de sua observância como critério de reconhecimento comparativo das fases polares (Figura 6). 
FASE POLAR CHIKV

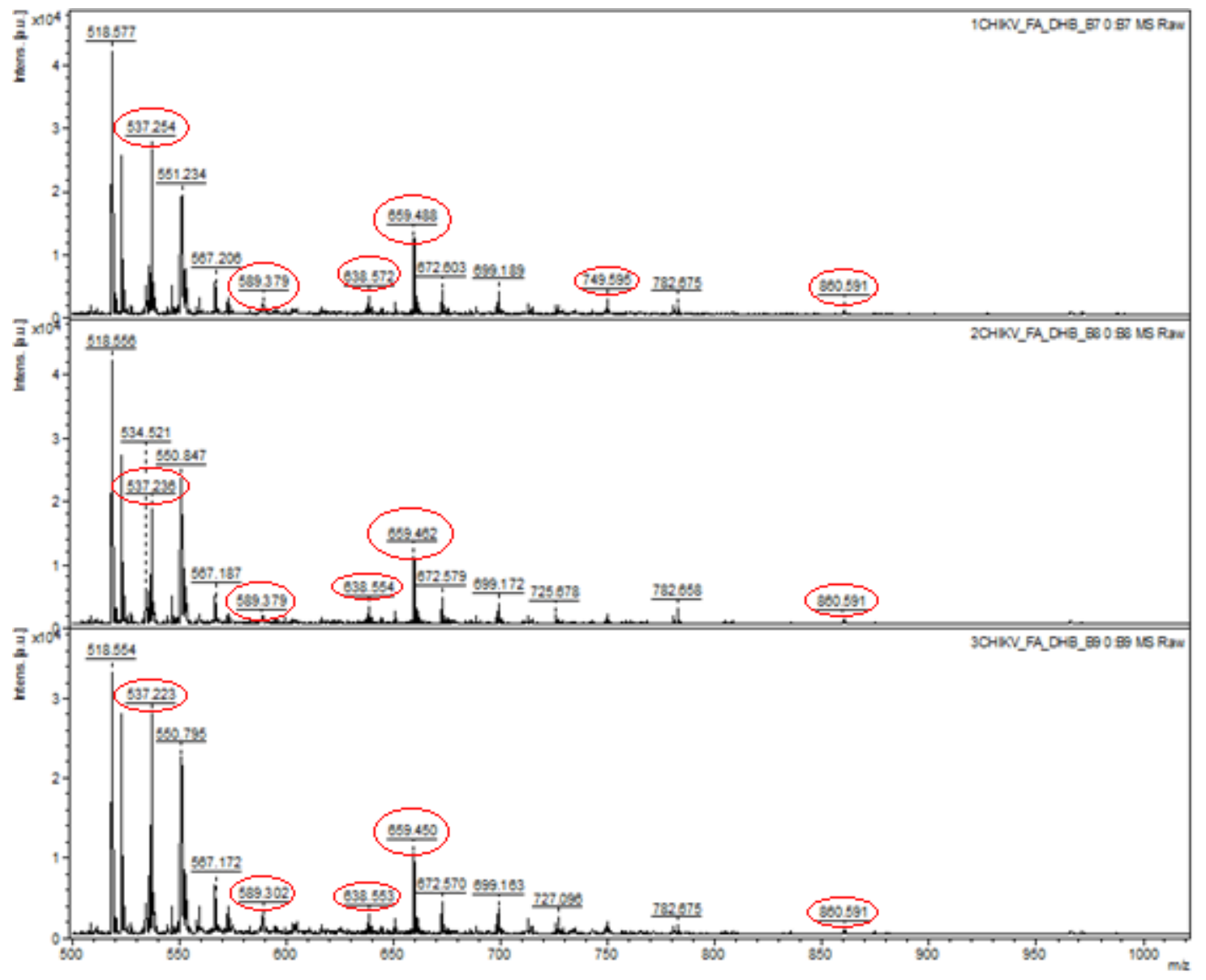

Figura 4 - TIC (total ion current chromatogram) do perfil da fase polar do CHIKV. Em evidência, os íons $537 \mathrm{~m} / \mathrm{z}$, $638 \mathrm{~m} / \mathrm{z}, 659 \mathrm{~m} / \mathrm{z}, 749 \mathrm{~m} / \mathrm{z}$ e $860 \mathrm{~m} / \mathrm{z}$. 
FASE POLAR ZIKV

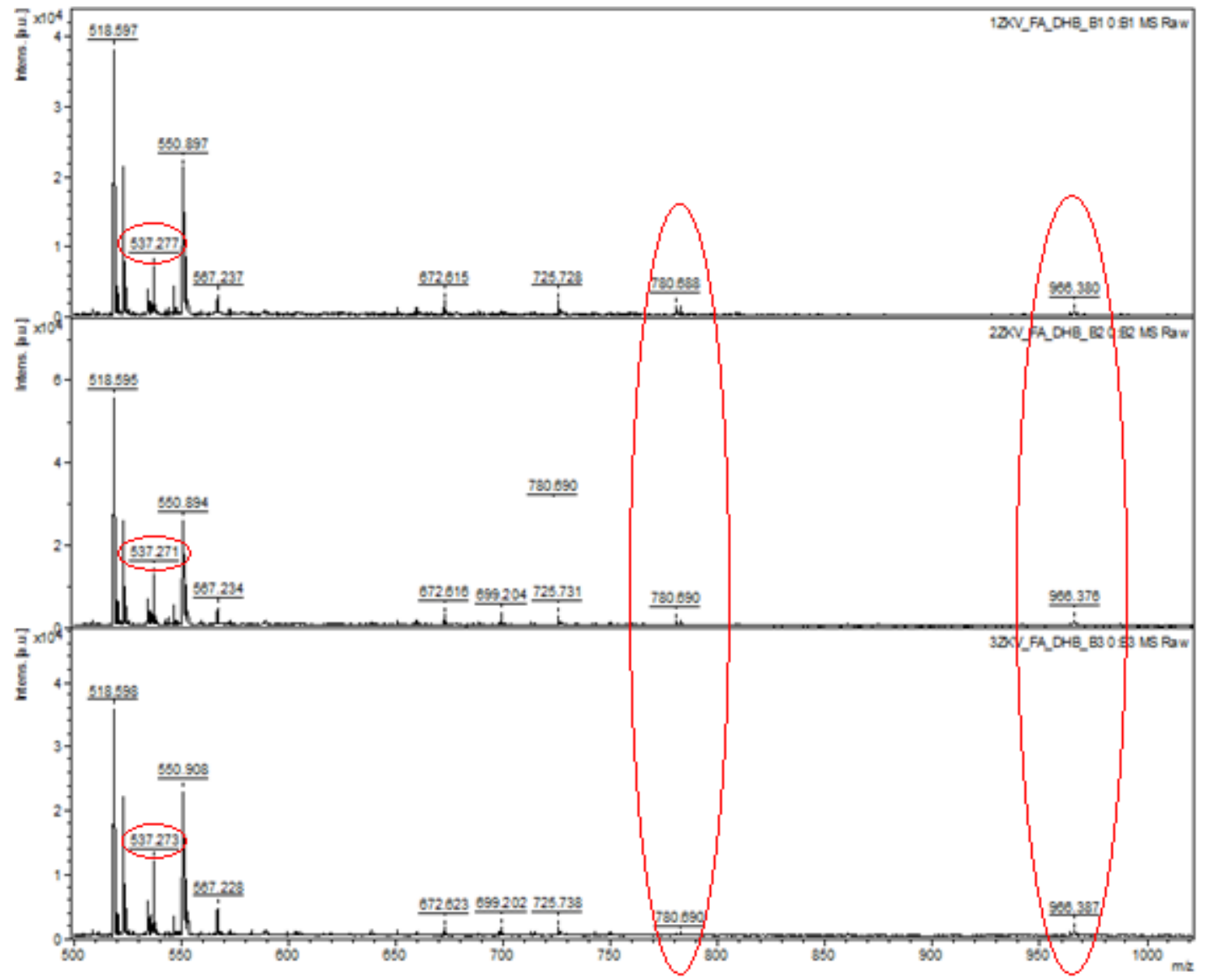

Figura 5 - TIC (total ion current chromatogram) do perfil da fase polar do CHIKV. Em evidência, os íons $537 \mathrm{~m} / \mathrm{z} \mathrm{e}$ os intervalos $567-672 \mathrm{~m} / \mathrm{z}$ e $780-966 \mathrm{~m} / \mathrm{z} .638 \mathrm{~m} / \mathrm{z}, 659 \mathrm{~m} / \mathrm{z}, 749 \mathrm{~m} / \mathrm{z}$ e $860 \mathrm{~m} / \mathrm{z}$.

FASE POLAR: COMPARATIVO

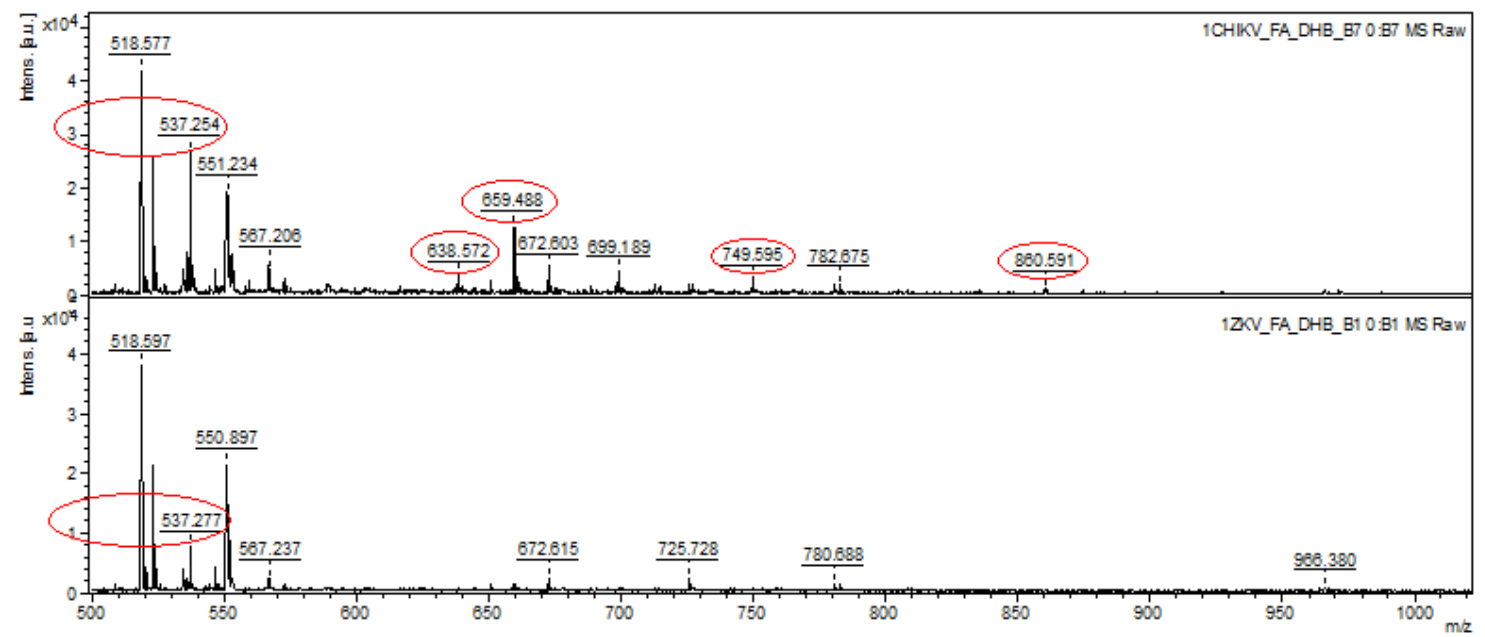

Figura 6 - TIC (total ion current chromatogram) do perfil lipídico comparativo. 


\subsection{PERFIL PEPTÍDICO}

O perfil peptídico também foi analisado e a leitura do CHIKV (Figura 7) não apresentou íons significativos. Não obstante a este resultado, o perfil do ZIKV (Figura 8) apresentou o íon $5020 \mathrm{~m} / \mathrm{z}$ com intensidade em torno de $2.10^{4}$ que o torna bastante específico como é demonstrado no quadro comparativo dos perfis peptídicos (Figura 9).

\section{PERFIL PEPTÍDICO CHIKV}

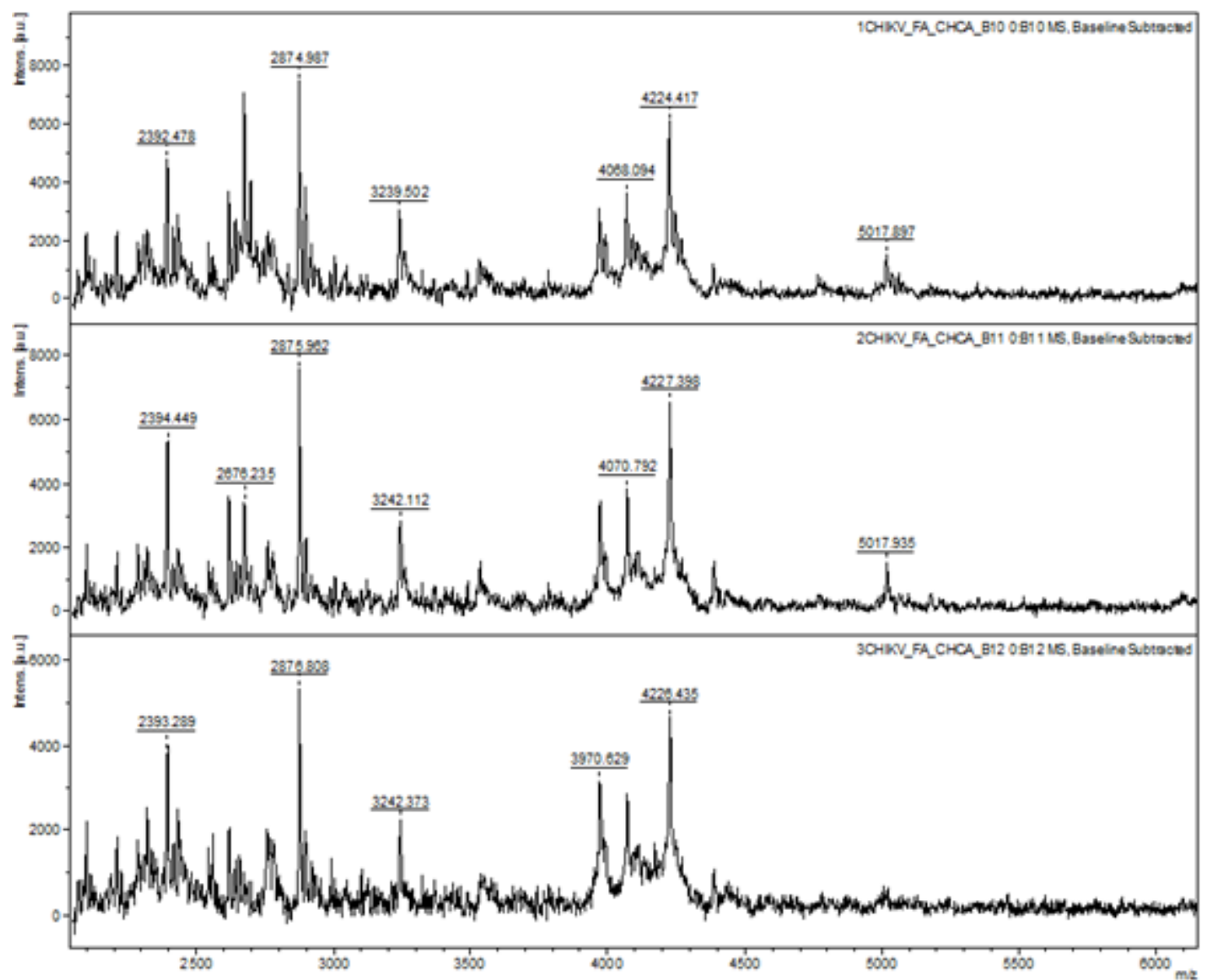

Figura 7 - TIC (total ion current chromatogram) peptídico do CHIKV.

\section{PERFIL PEPTÍDICO DO ZIKV}




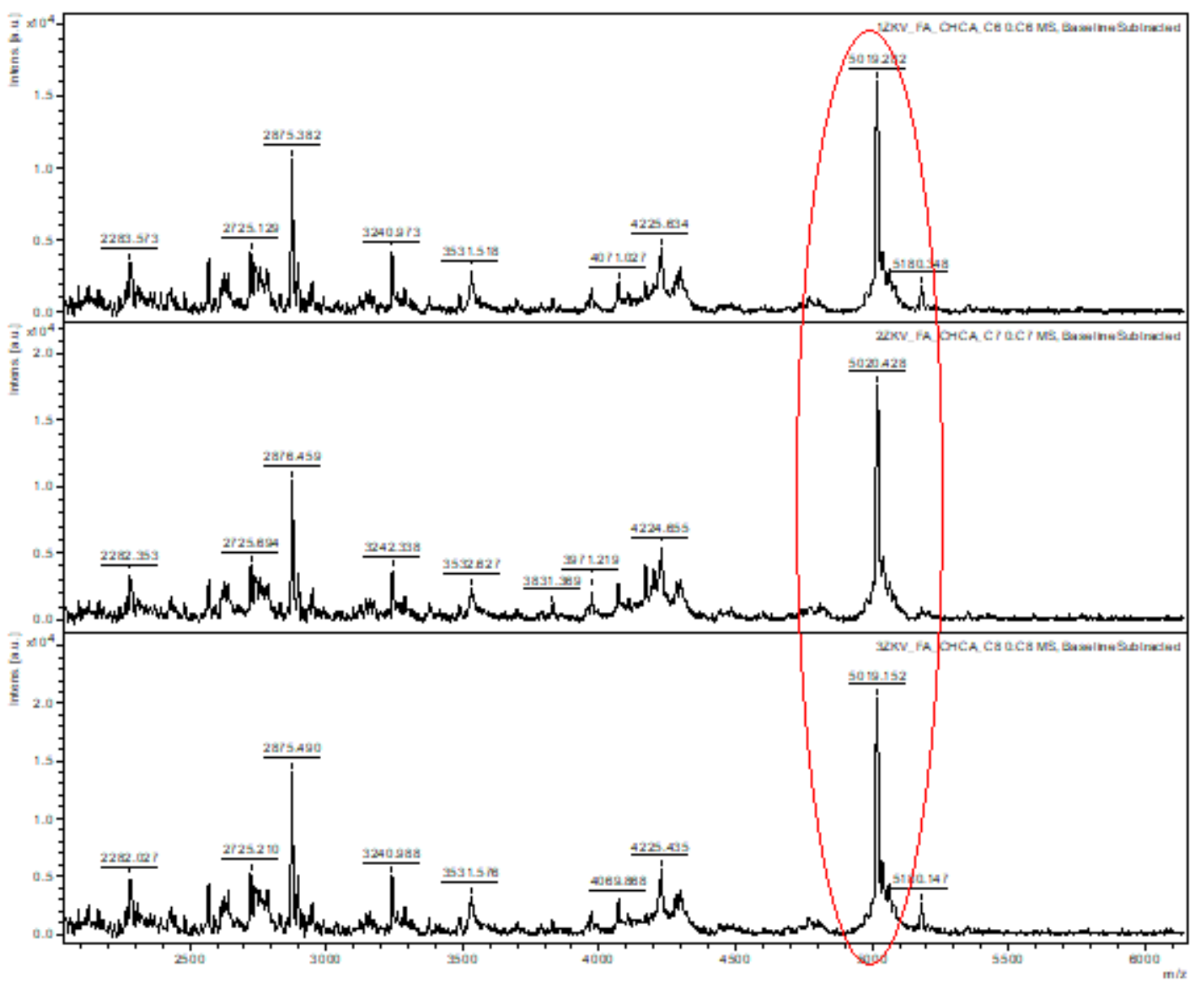

Figura 8 - TIC (total ion current chromatogram) peptídico do ZIKV.

PERFIL PEPTÍDICO COMPARATIVO

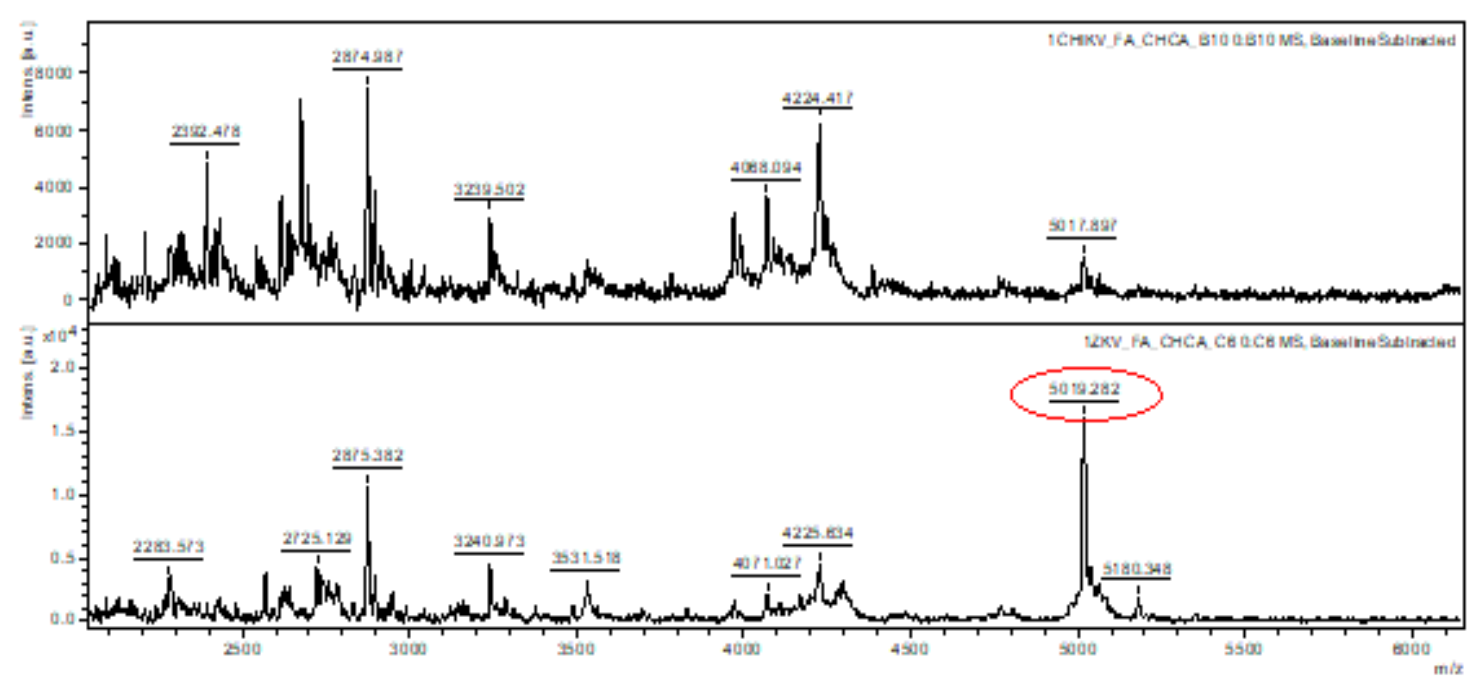

Figura 9 - TIC (total ion current chromatogram) peptídico comparativo.

SEPN 707/907, campus do UniCEUB, 70790-075, Brasília-DF

(61) 3966-1200 - www.uniceub.br 


\section{CONSIDERAÇÕES FINAIS}

Os resultados das análises das amostras apontam-se promissores quanto à existência de íons marcadores para identificar as arboviroses Chigungunya e Zika, demonstrando avanço frente ao diagnóstico dessas duas doenças com diferenciação clínica difícil.

O método utilizado é possível de ser reproduzido fora do laboratório, basta que a instituição, hospitalar, clínica ou acadêmica, possua a instrumentação para análise. Dessa forma, os resultados mostram-se reais frente à aplicação prática de sua utilização nos sistemas de saúde.

Conclui-se, portanto, que há uma especificidade apresentada por esses íons referentes a diferentes moléculas que possibilitam identificar de maneira rápida o fingerprint destas doenças, tornando muitos deste íons, íons marcadores de diagnóstico e discriminantes metabólicos. Essa utilização de discriminantes para rápido diagnóstico molecular de arboviroses representa uma das melhores alternativas para o futuro de seus diagnósticos.

\section{REFERÊNCIAS}

FAUCI, A.S.; MORENS, D.M. The perpetual challenge of infectious diseases. N Engl J Med. 366 (2012) 454-461.

OLIVEIRA, CS; VASCONCELOS, PFC. Microcephaly and Zika virus. J Pediatr, 92(2): 103-105, 2016.

KUCHARZ, E.J.; CEBULA-BYRSKA, I. Chikungunya fever. Eur J Intern Med. 23 (2012) 325-329.

BORTEL, W et al. Chikungunya outbreak in the Caribbean region, December 2013 to March 2014, and the significance for Europe. Eurosurveillance, 19(13): [on line], 2014.

MINISTÉRIO DA SAÚDE. Boletim Epidemiológico-Secretaria de Vigilância em Saúde. Volume 47, Nº 10, 2016.

COLÓN-GONZÁLEZ, FJ et al. After the epidemic: Zika virus projections for Latin America and the Caribbean. PLOS Neglected Tropical Deseases, 10: 1-19, 2017. 
EASTWOOD, G et al. Enzootic Circulation of Chikungunya Virus in East Africa: Serological Evidence in Non-human Kenyan Primates. Am. J. Trop. Med. Hyg., 97(5): 1399-1404, 2017.

TAMBO, E et al. Ethical, legal and societal considerations on Zika virus epidemics complications in scaling-up prevention and control strategies. Ethics, and Humanities in Medicine, 12(3): 1-8, 2017.

GÖERTZ, GP et al. Mosquito co-infection with Zika and chikungunya virus allows simultaneous transmission without affecting vector competence of Aedes aegypti. PLOS Neglected Tropical Diseases, 10: 1-22, 2017.

MURRAY, KO et al. Prolonged detection of Zika virus in vaginal secretions and whole blood. Emerging Infectious Diseases, 23(1): 99-101, 2017.

GODAERT, L et al. Screening for Chikungunya virus infection in aged people: Development and internal validation of a new score. PLOS ONE, 10.1371: 1-9, 2017.

SILVA, MR et al. Suppression of chikungunya virus replication and differential innate responses of human peripheral blood mononuclear cells during coinfection with dengue virus. PLOS Neglected Tropical Diseases, 10: 1-15, 2017.

MOORE, CA et al. Characterizing the pattern of anomalies is congenital Zika syndrome for pediatric clinicians. JAMA Pediatrics, 171(3): 288-295, 2017.

MALTA, JMAS et al. Síndrome de Guillain-Barré e outras manifestações neurológicas possivelmente relacionadas à infecção pelo vírus Zika em municípios da Bahia, 2015. Epidemiol Serv Saúde, 26(1): 9-18, 2017.

GIRY, $C$ et al. Simultaneous detection of chikungunya virus, dengue virus and human pathogenic Leptospira genomes using a multiplex TaqMan® assay. BMC Microbiology, 17(105): 1019-1030, 2017.

WOROBEY, M. Molecular mapping of Zika spread. Nature, 546: 355-356, 2017.

SACZYŃSKA, V et al. Production of highly and broad-range specific monoclonal antibodies against hemagglutinin of H5-subtype avian influenza viruses and their differentiation by mass spectrometry. Virology Journal, 15(13): 1-13, 2018.

GAO, D; CAZARES, LH; FISH, EN. CCL5-CCR5 interactions modulate metabolic events during tumor onset to promote tumorigenesis. BMC Cancer, 17(834): 1-13, 2017.

KAN, F et al. Proteomic and transcriptomic studies of HBV-associated liver fibrosis of an AAVHBV - infected mouse model. BMC Genomics, 18(641): 1-16, 2017.

CLAUS, C; LIEBERT, UG. A renewed focus on the interplay between virusesand mitochondrial metabolismo. Arch Virol, 159: 1267-1277, 2014. 
PASSOS-CASTILHO, AM et al. Plasma Lipidomic Fingerprinting to Distinguish among Hepatitis C-related Hepatocellular Carcinoma, Liver Cirrhosis, and Chronic Hepatitis C using MALDI-TOF Mass Spectrometry: a Pilot Stud. J Gastrointestin Liver Dis, 24(1): 43-49, 2015.

KLITZKE, CF. Aplicações da espectrometria de massas de altíssima resolução e da mobilidade iônica acoplada à espectrometria de massas em estudos de geoquímica orgânica. Tese de doutorado apresentada ao Instituto de Química da Universidade de Campinas, 2012. 


\section{APÊNDICE}

1. GRÁFICOS DOS RESULTADOS DA ANÁLISE DO MÉTODO

BD DHB 60\% 1MI
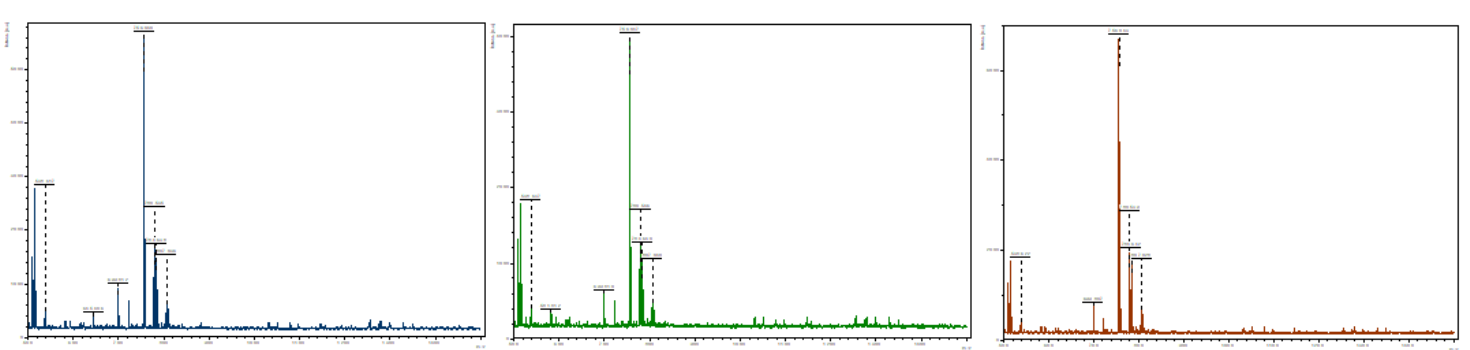

BD DHB 70\% 1MI
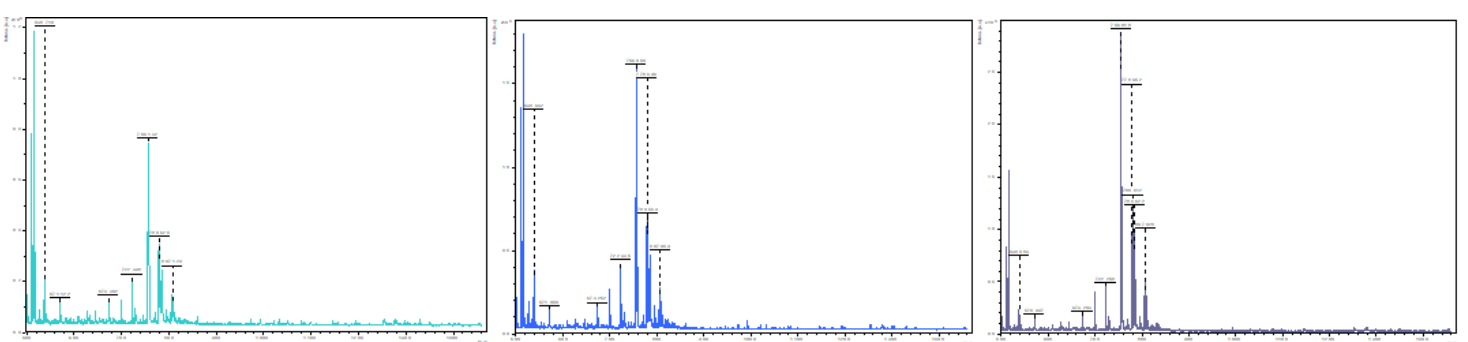

BD CIANO 60\% 1MI
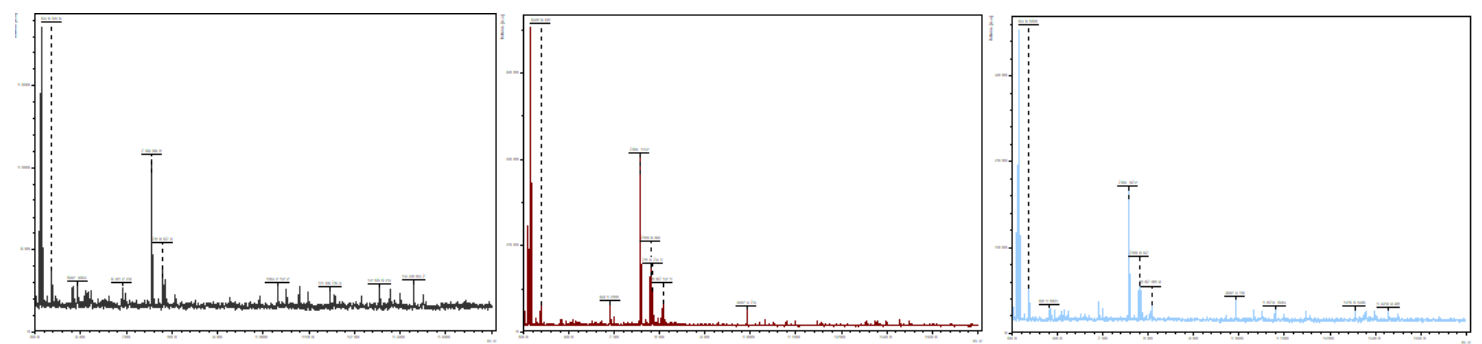

BD CIANO 70\% 1MI
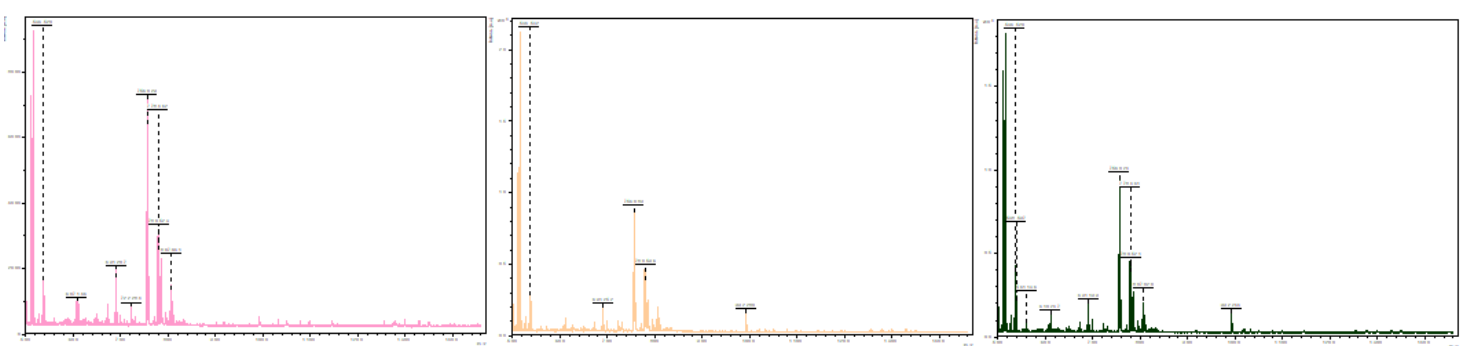
BD AMC 60\% 1MI
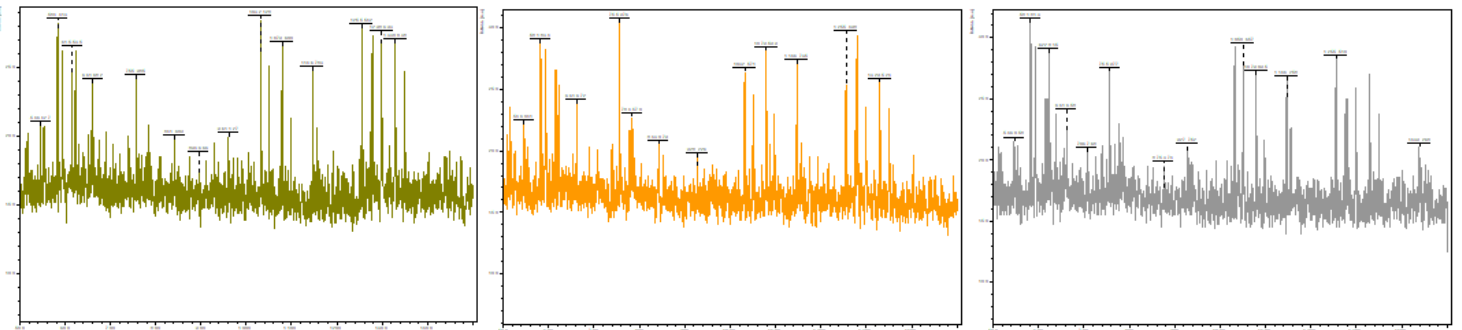

BD AMC 70\% 1MI
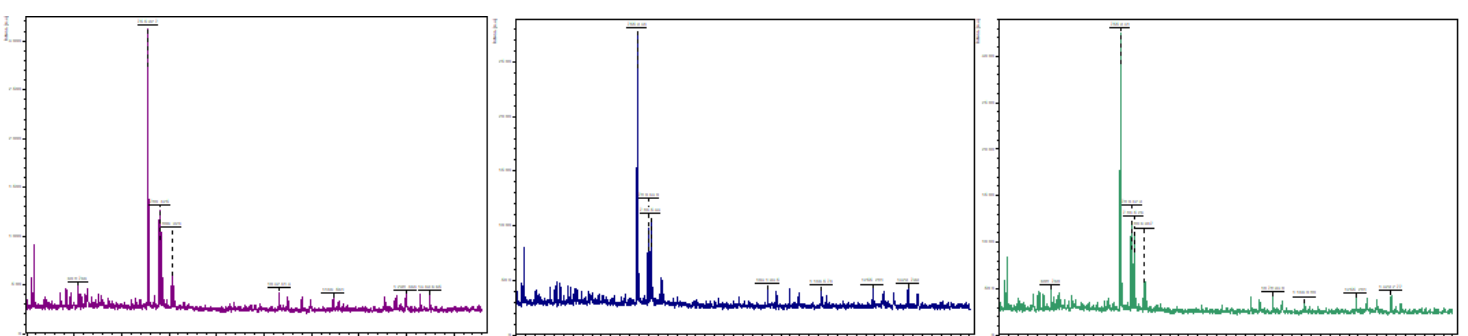

BD ATF $60 \% 1 \mathrm{MI}$
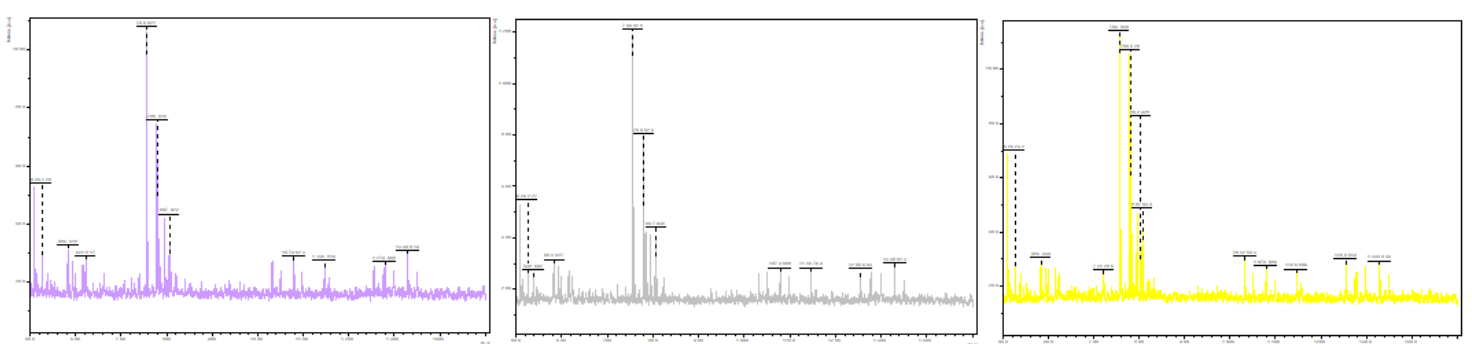

\section{BD ATF 70\% 1MI}
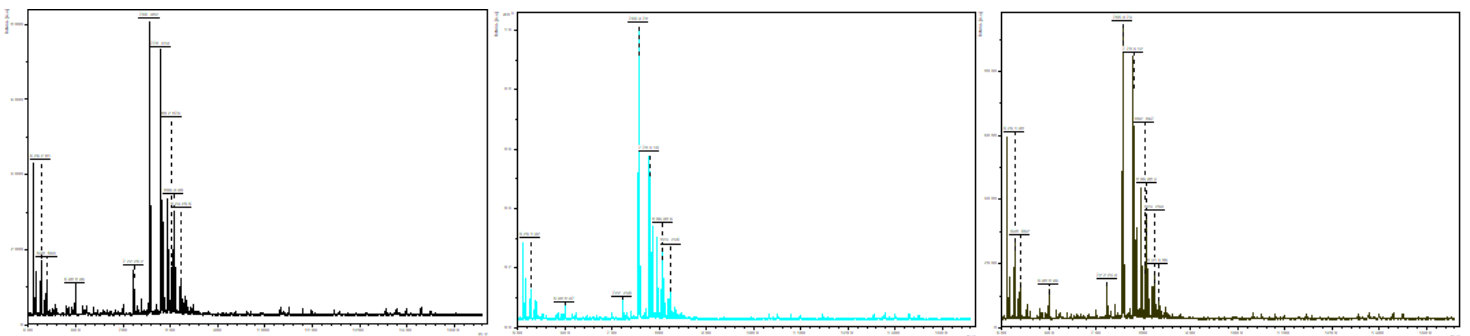

MTBE DHB 60\% 1MI
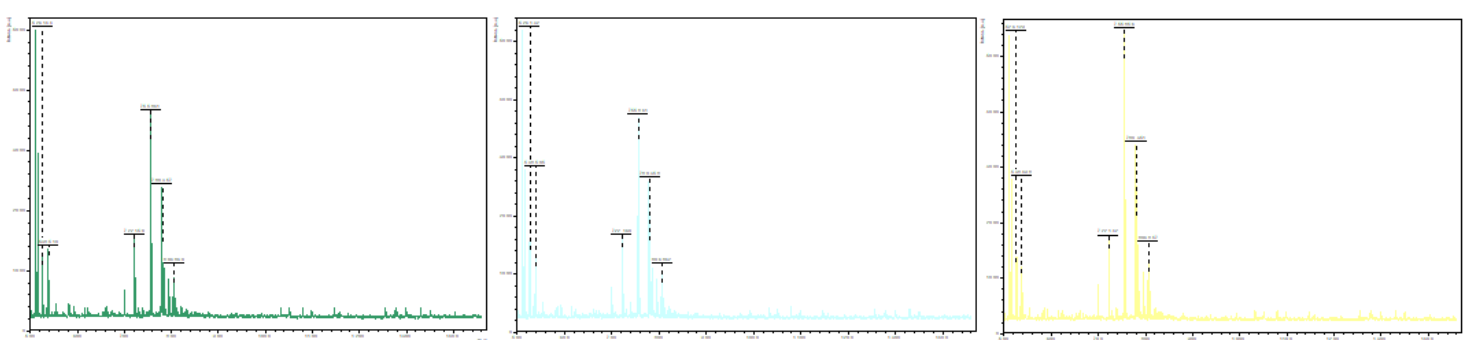
MTBE DHB 70\% 1MI
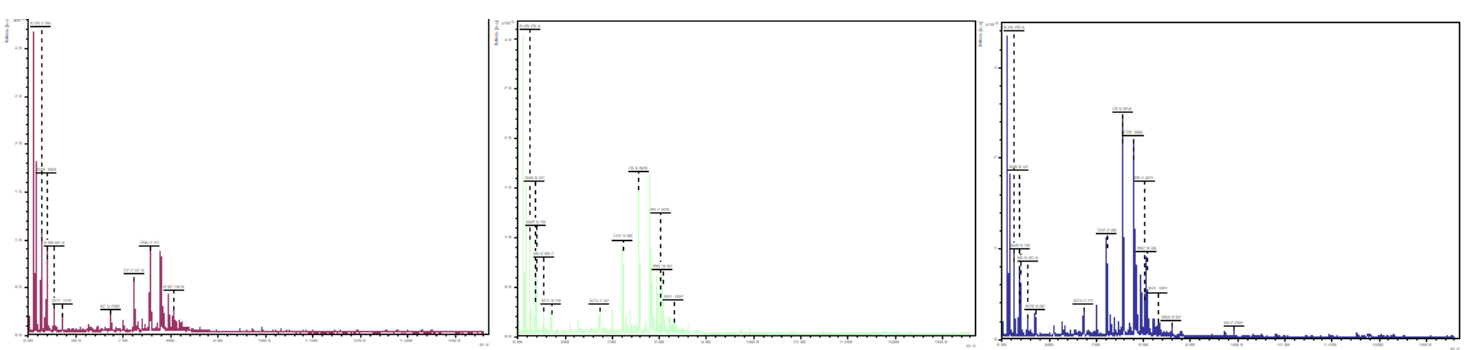

\section{MTBE CIANO 60\% 1MI}
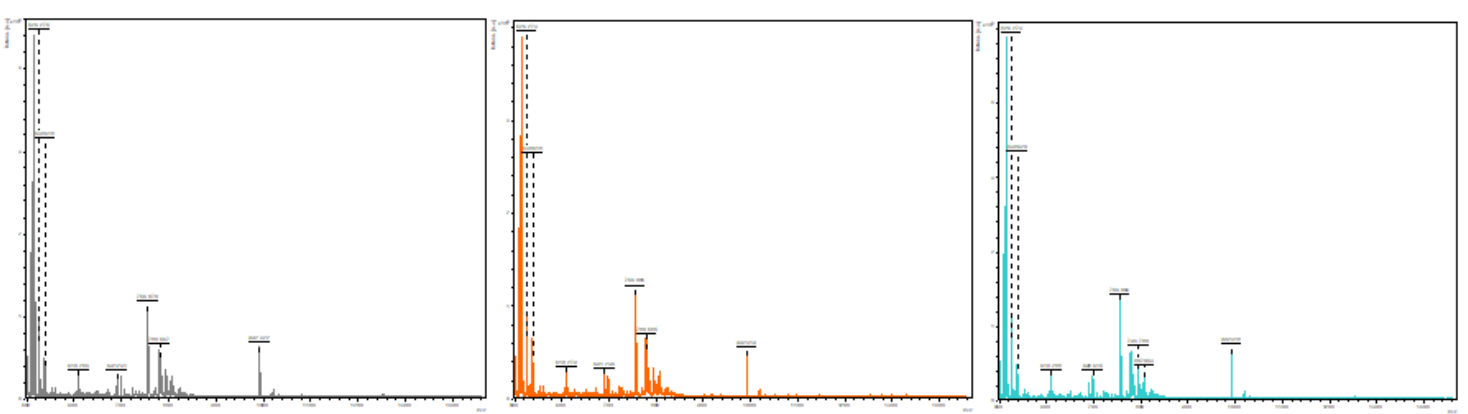

\section{MTBE CIANO 70\% 1MI}
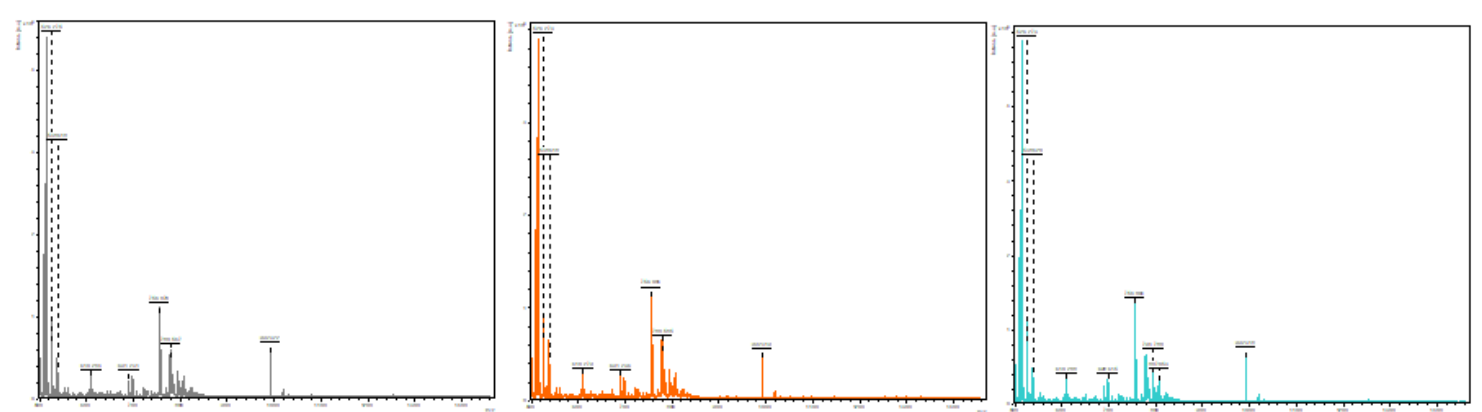

\section{MTBE AMC 60\% 1MI}
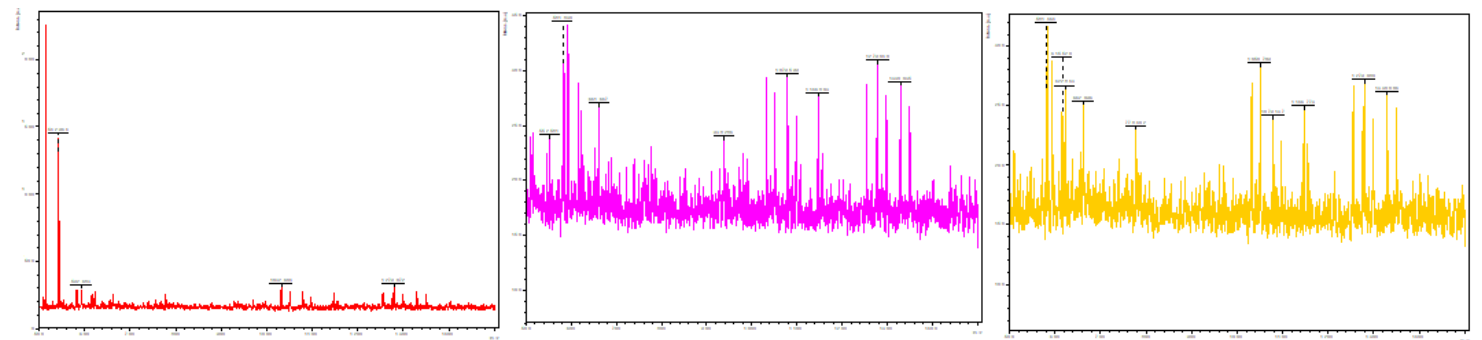

\section{MTBE AMC 70\% 1MI}
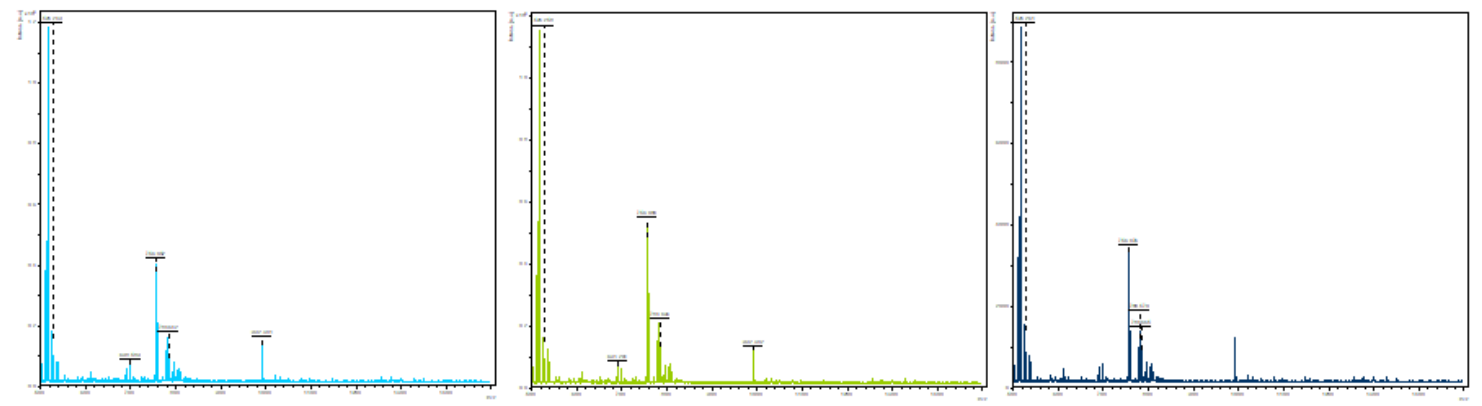

MTBE ATF 60\% 1MI 

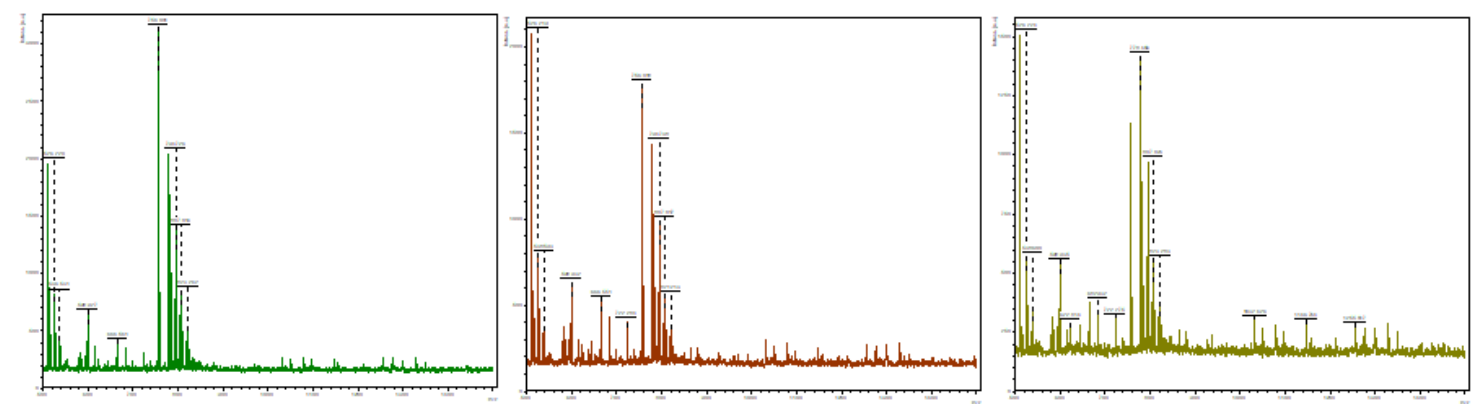

\section{MTBE ATF 70\% 1MI}
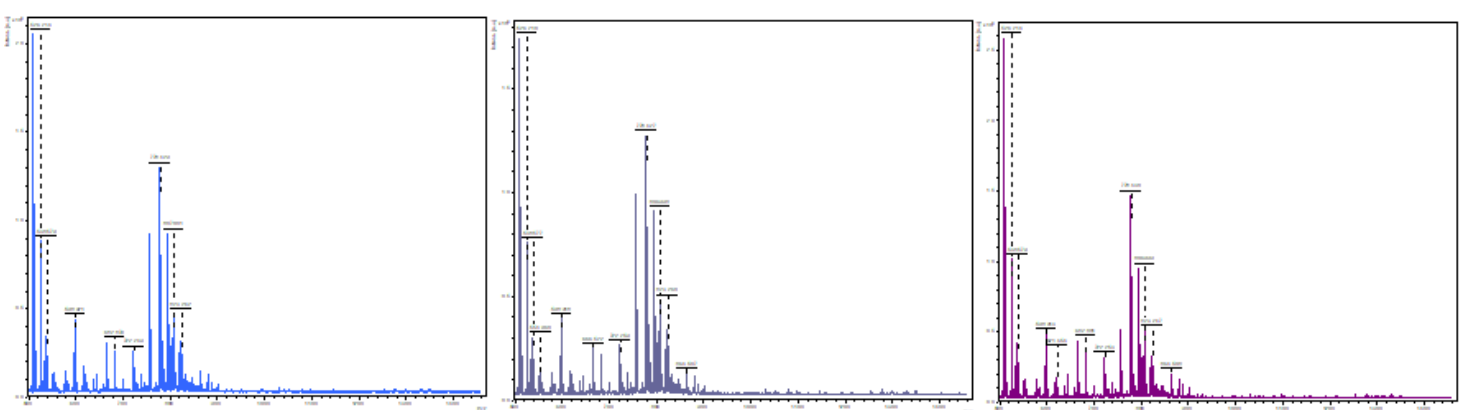

DB DHB 60\% 0.5MI
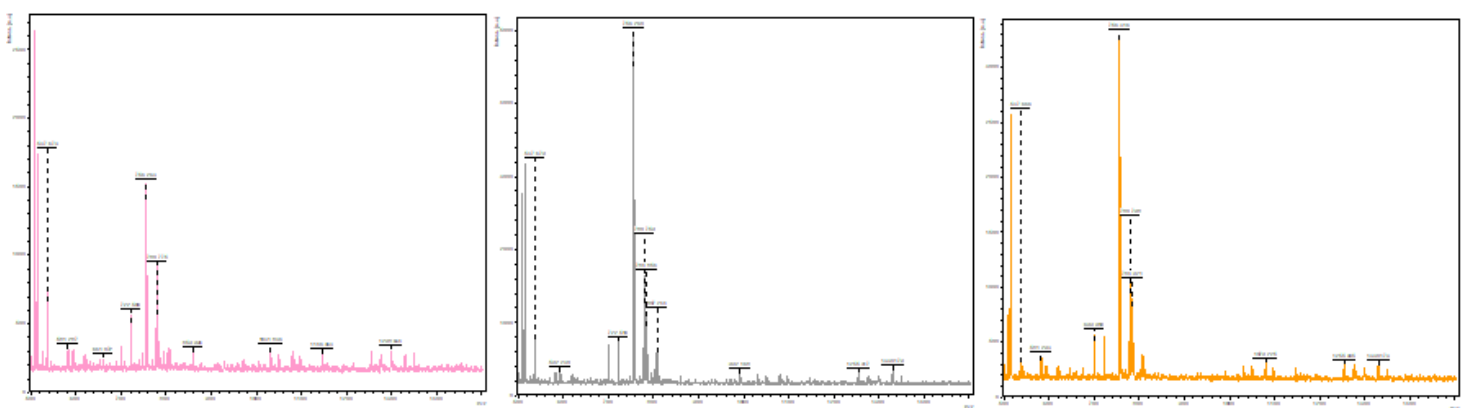

BD DHB 70\% 0.5MI
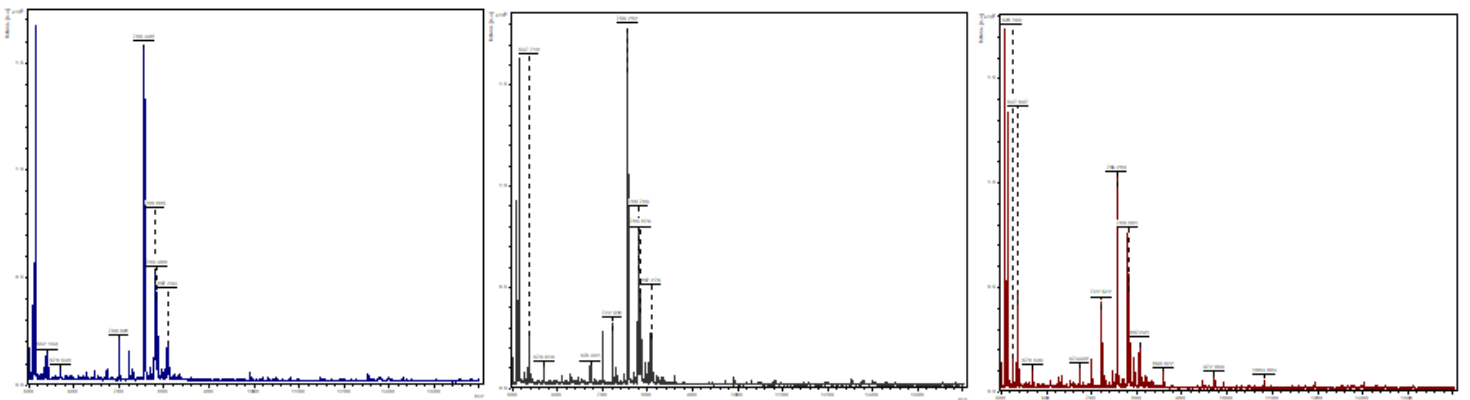

BD CIANO 60\% 0.5MI 

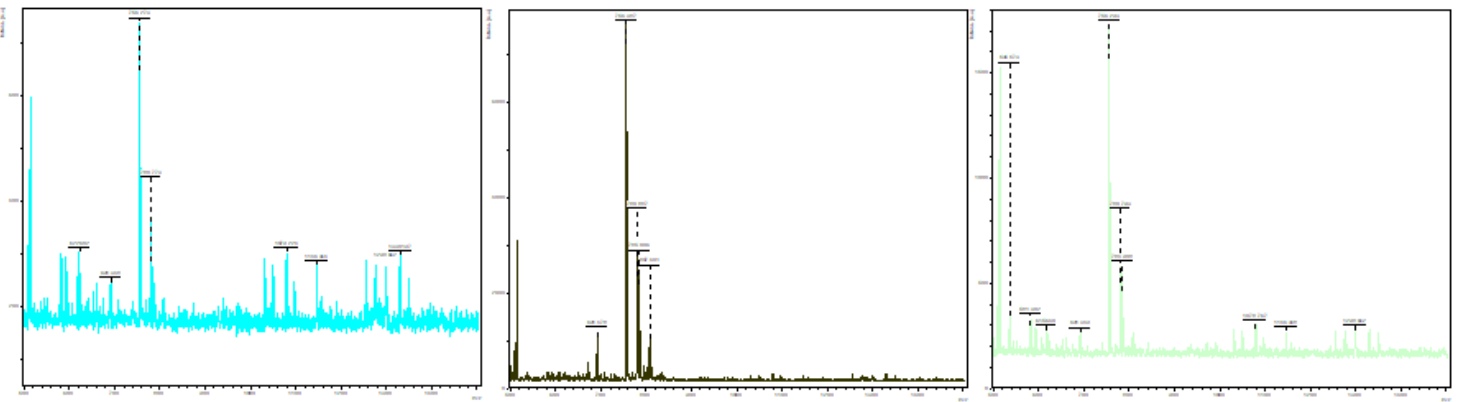

BD CIANO 70\% 0.5MI
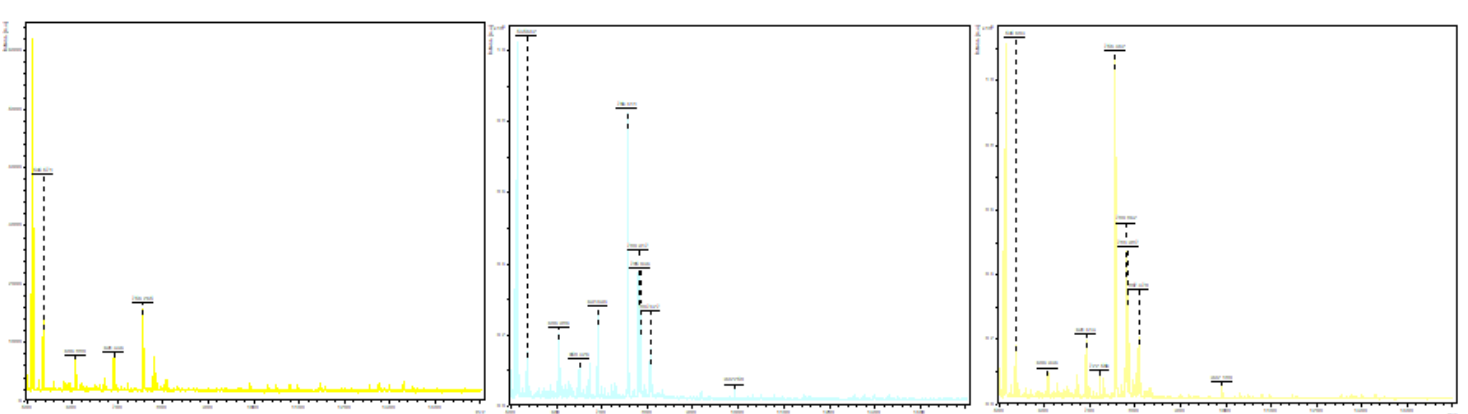

BD AMC $60 \% 0.5 \mathrm{MI}$
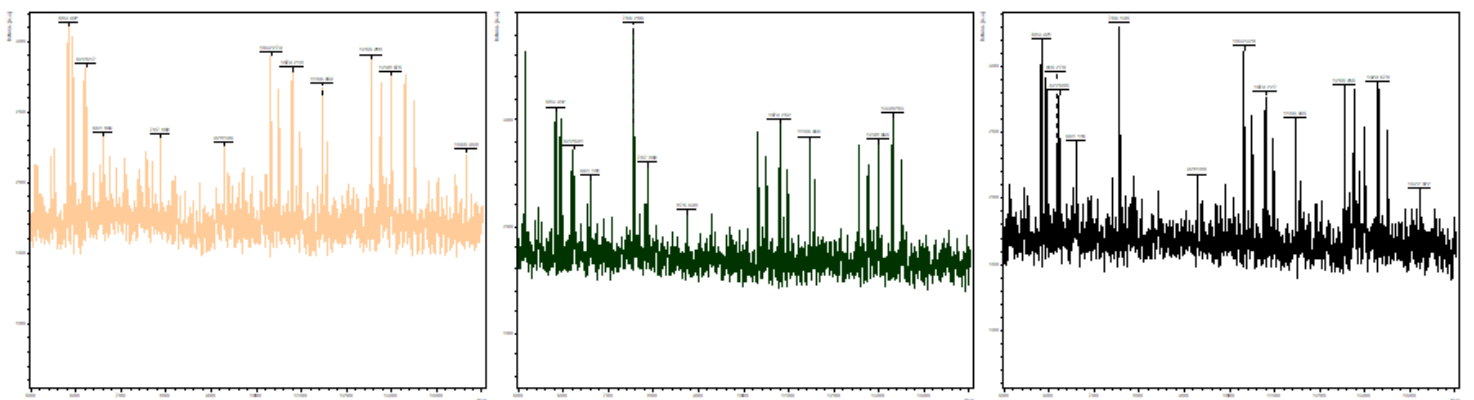

BD AMC 70\% 0.5MI
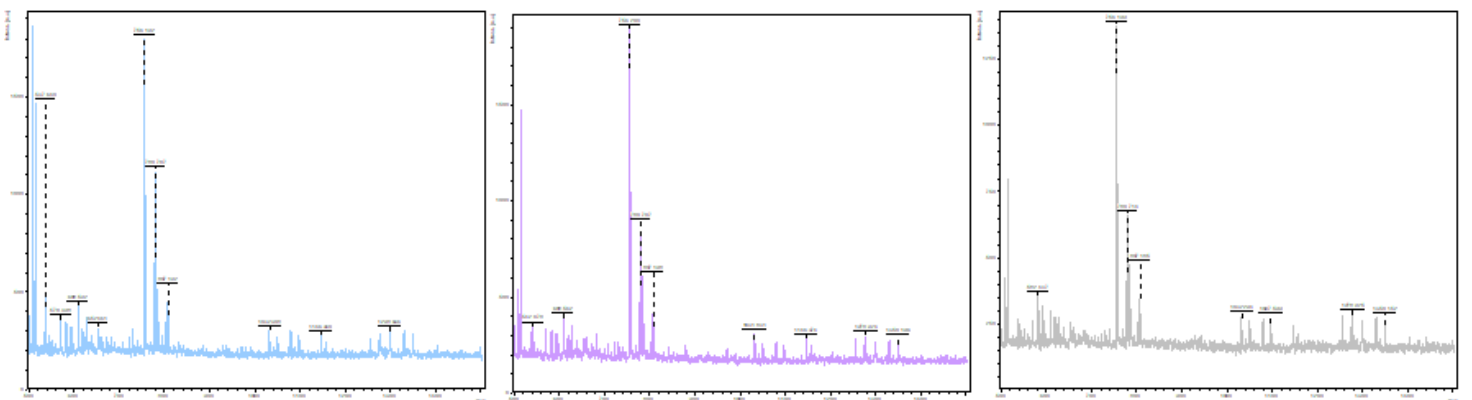
BD ATF $60 \% 0.5 \mathrm{MI}$
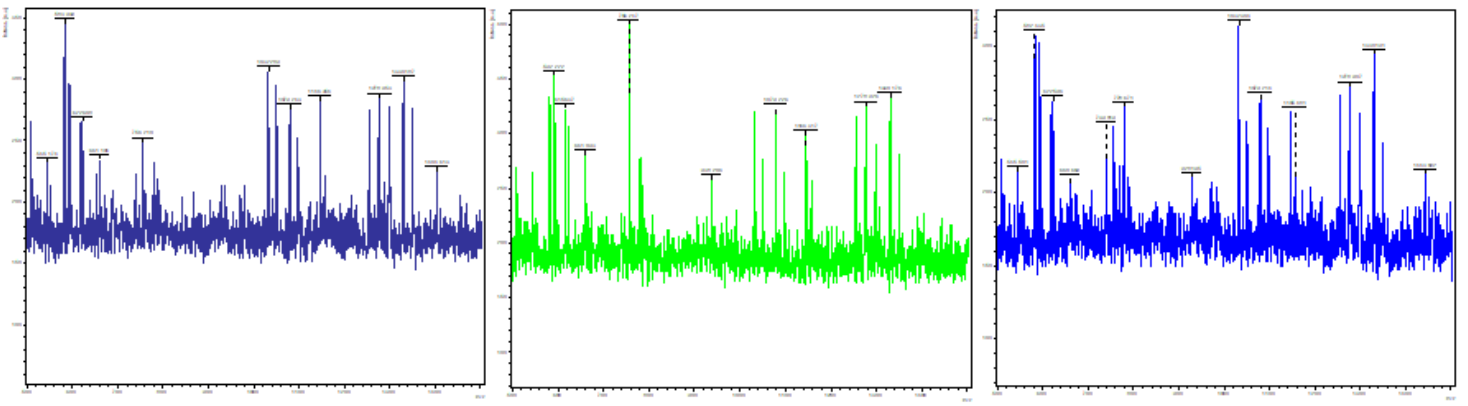

BD ATF 70\% 0.5MI
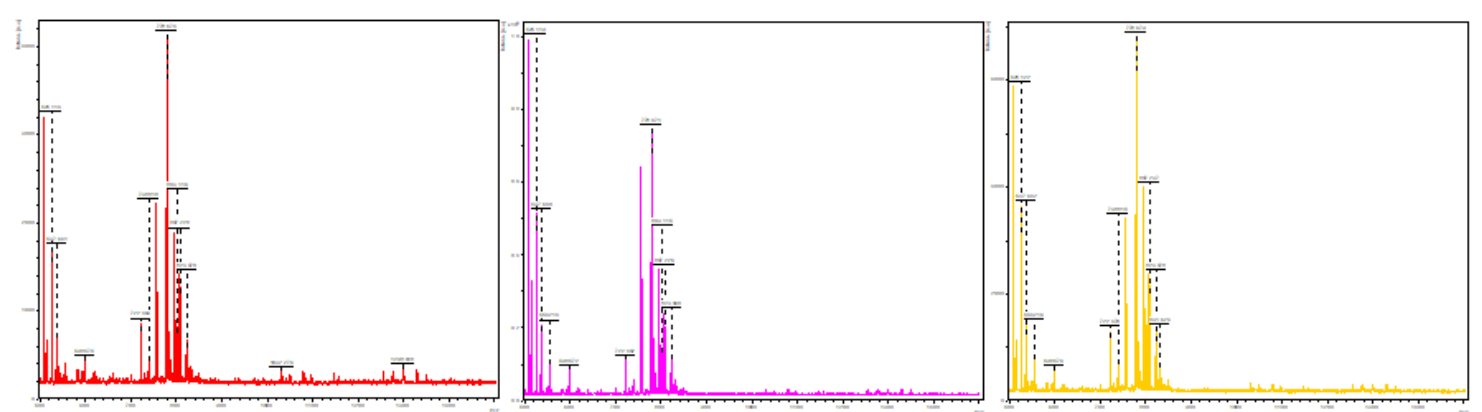

MTBE DHB 60\% 0.5MI
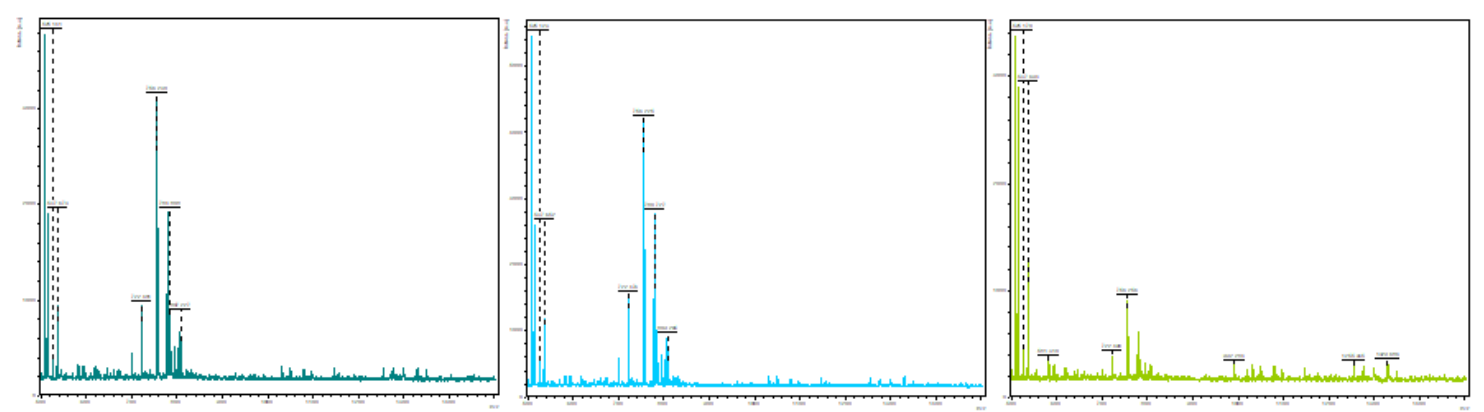

MTBE DHB 70\% 0.5MI
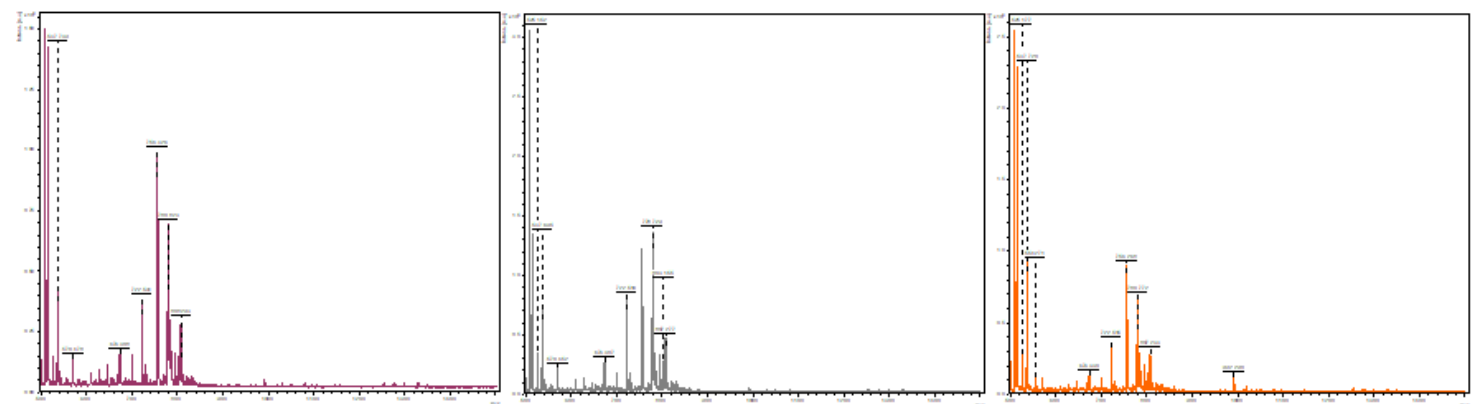
MTBE CIANO 60\% 0.5MI
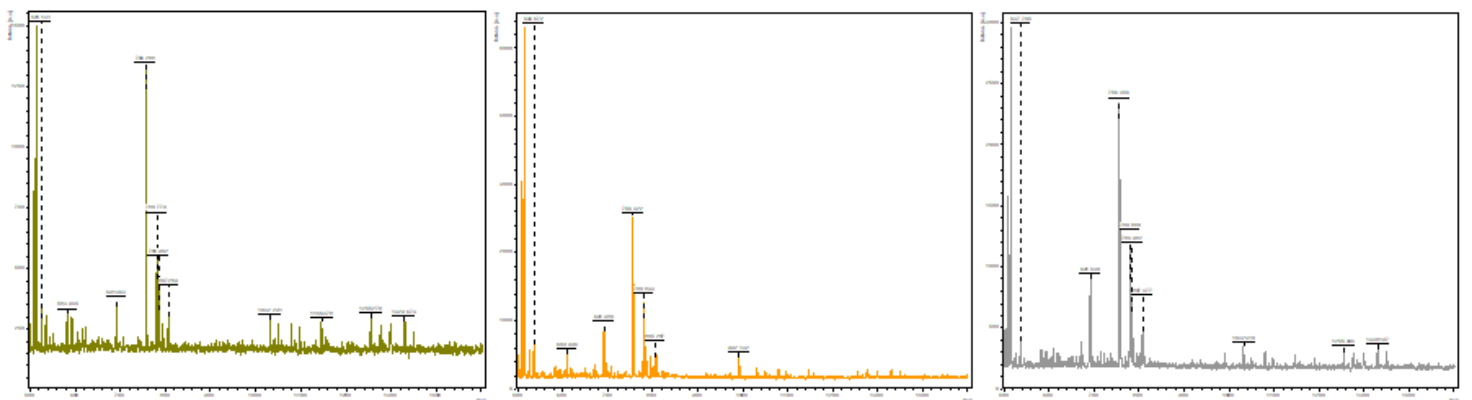

MTBE CIANO 70\% 0.5MI
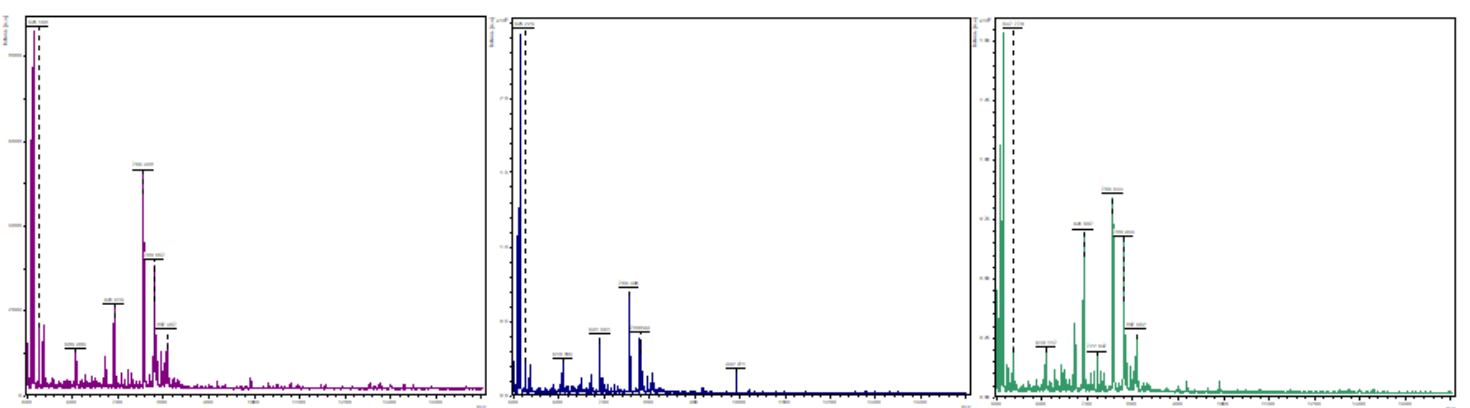

MTBE AMC $60 \% 0.5 \mathrm{MI}$
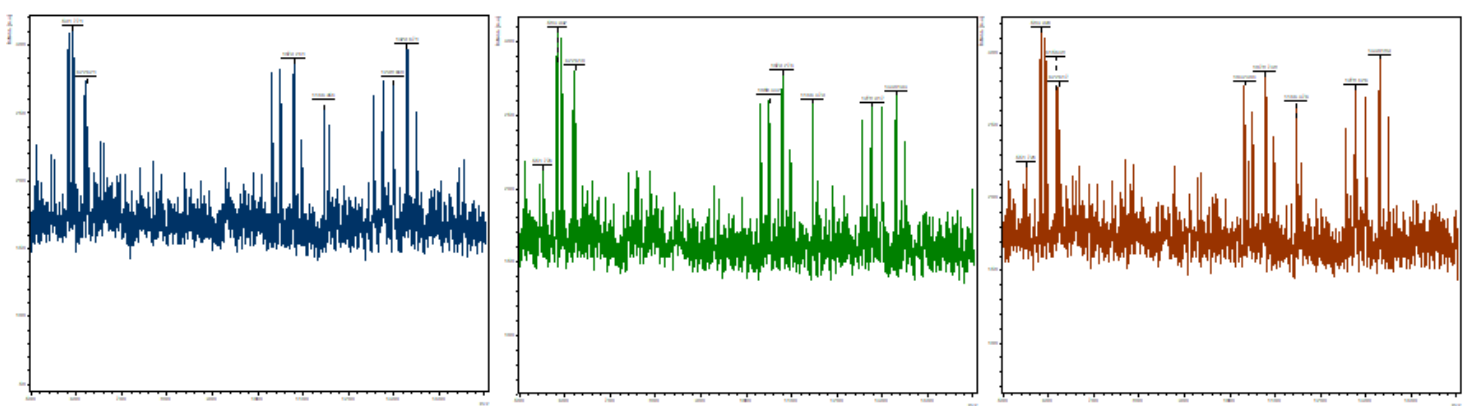

MTBE AMC 70\% 0.5MI
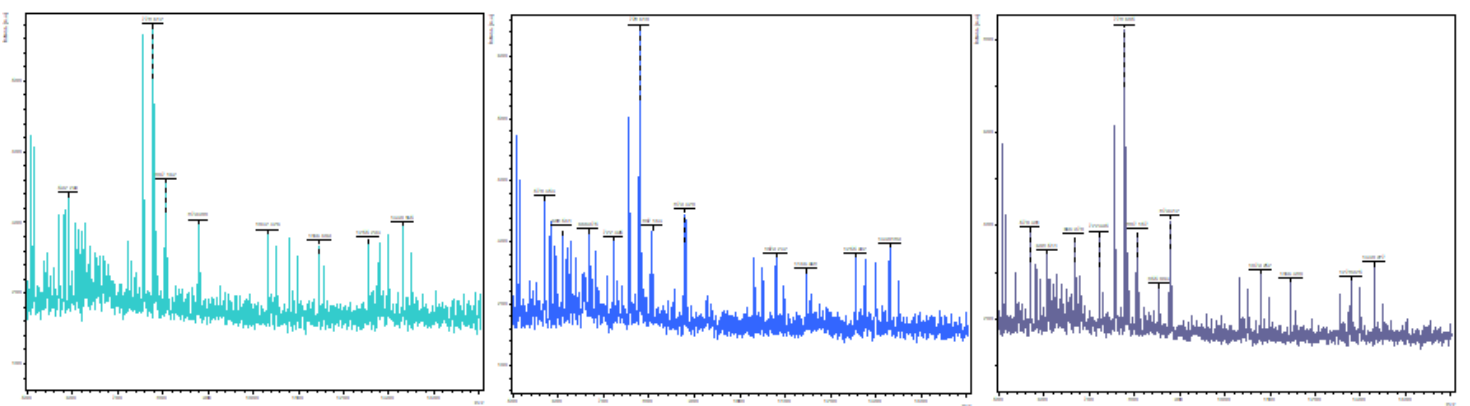
MTBE ATF $60 \%$ 0.5MI
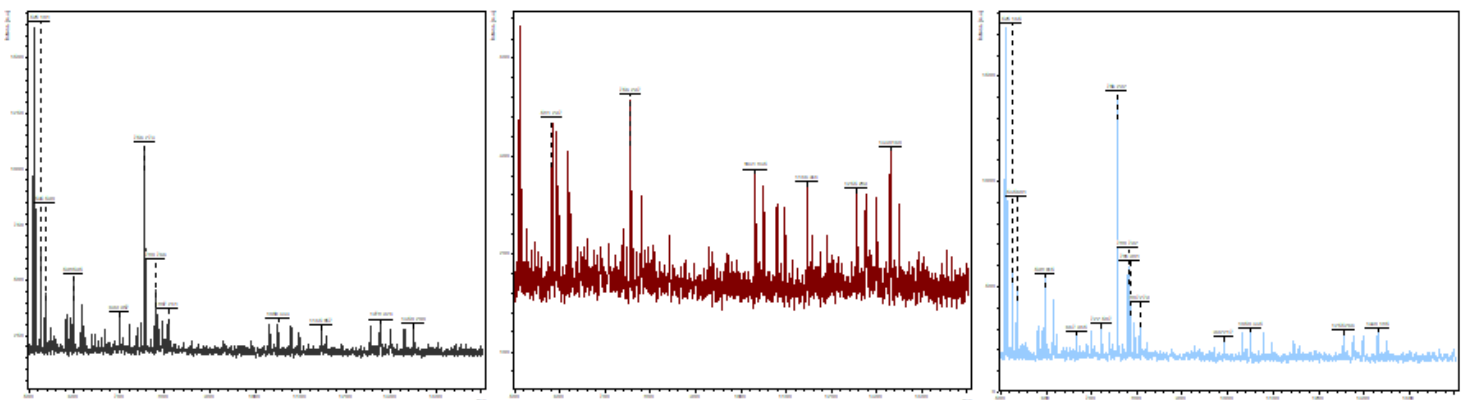

MTBE ATF 70\% 0.5MI
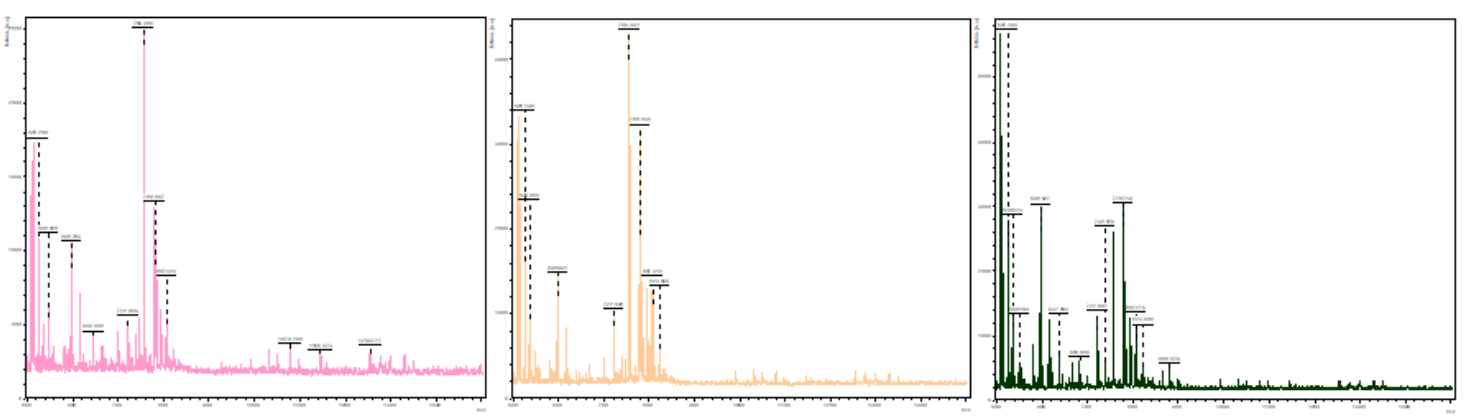

DB DHB 60\% 1.5MI
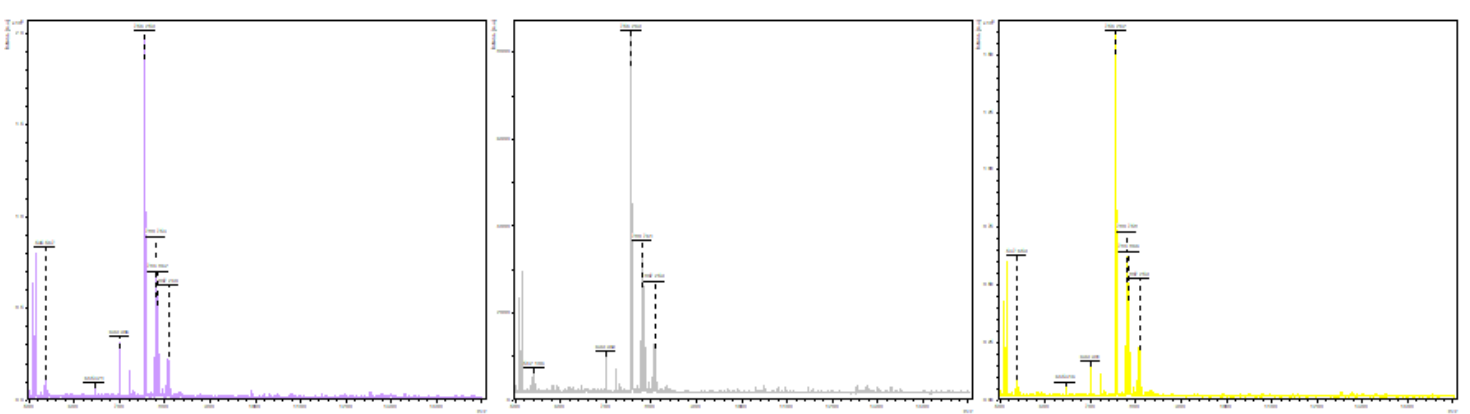

DB DHB 70\% 1.5MI
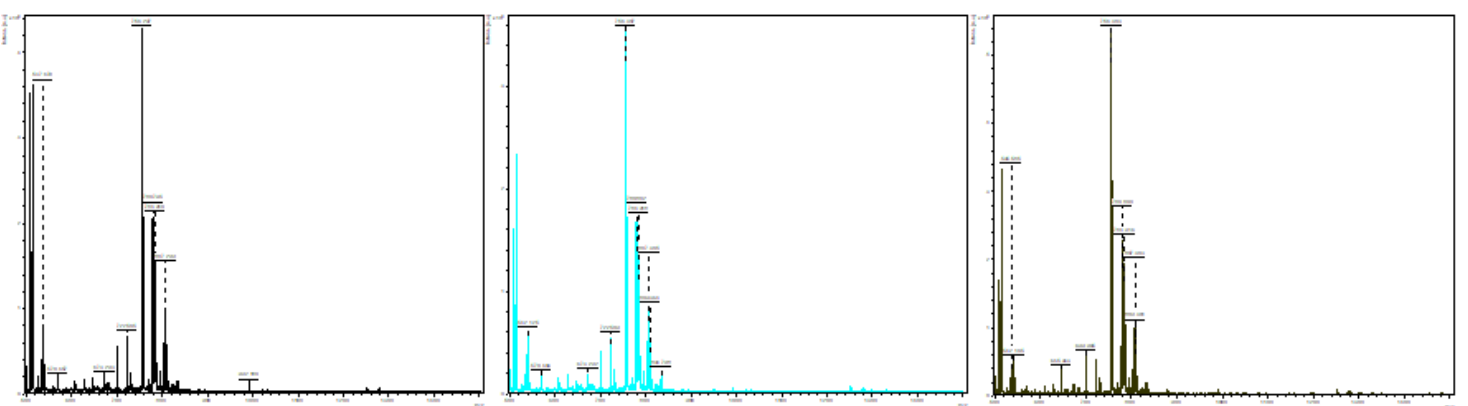
DB CIANO 60\% 1.5MI
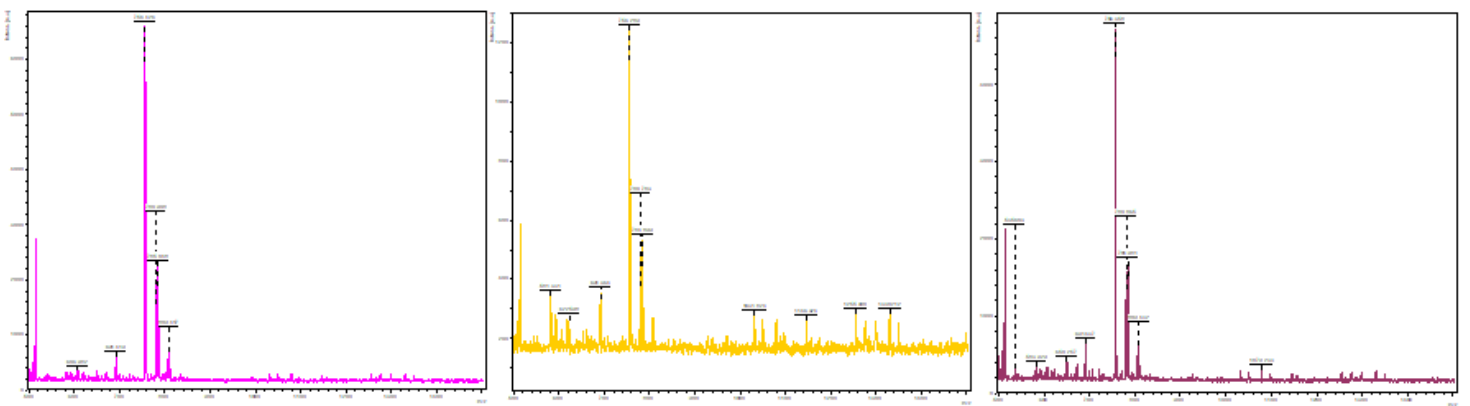

DB CIANO 70\% 1,5MI
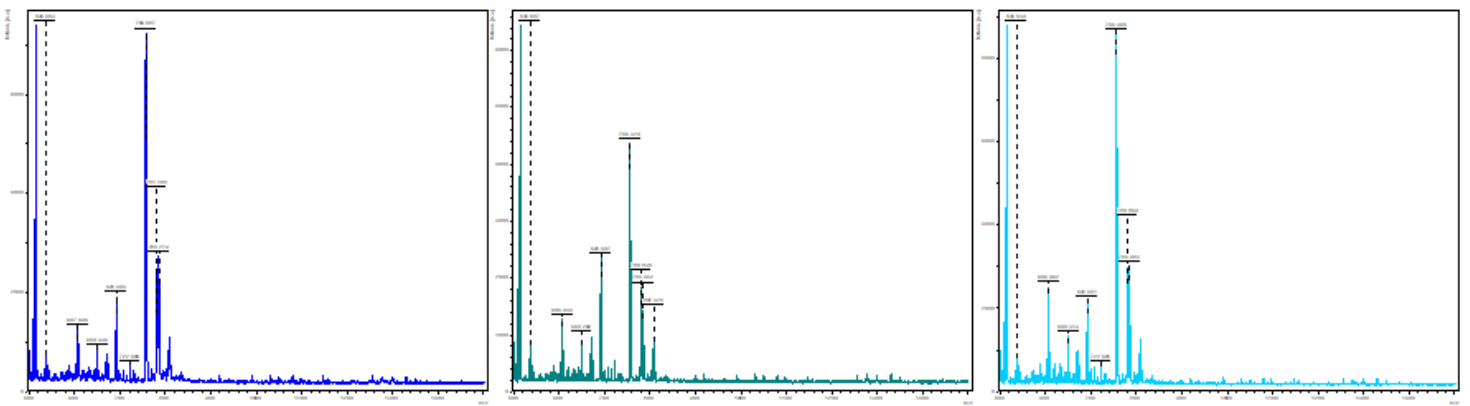

DB AMC 60\% 1.5MI
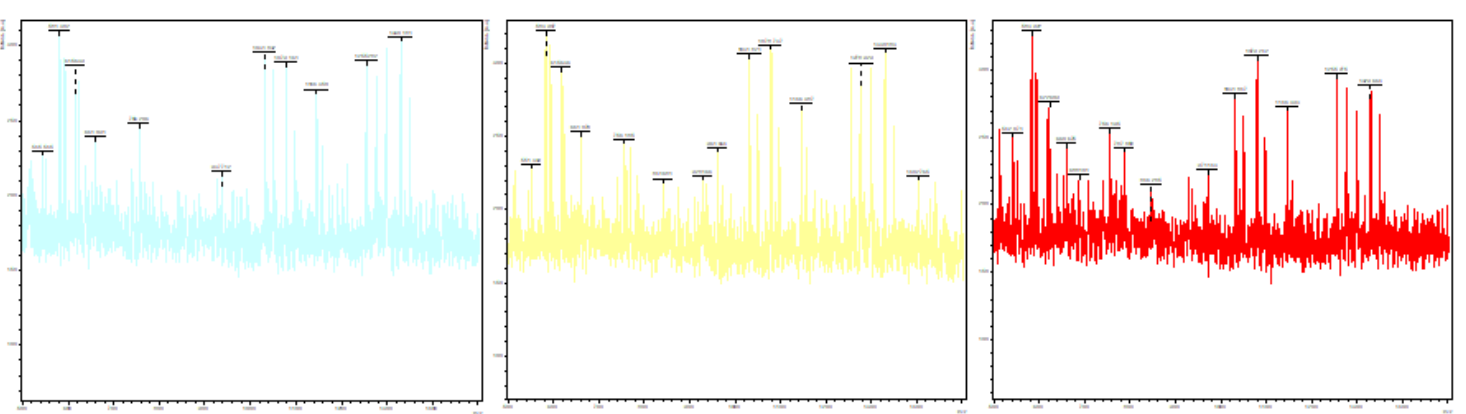

DB AMC 70\% 1.5MI
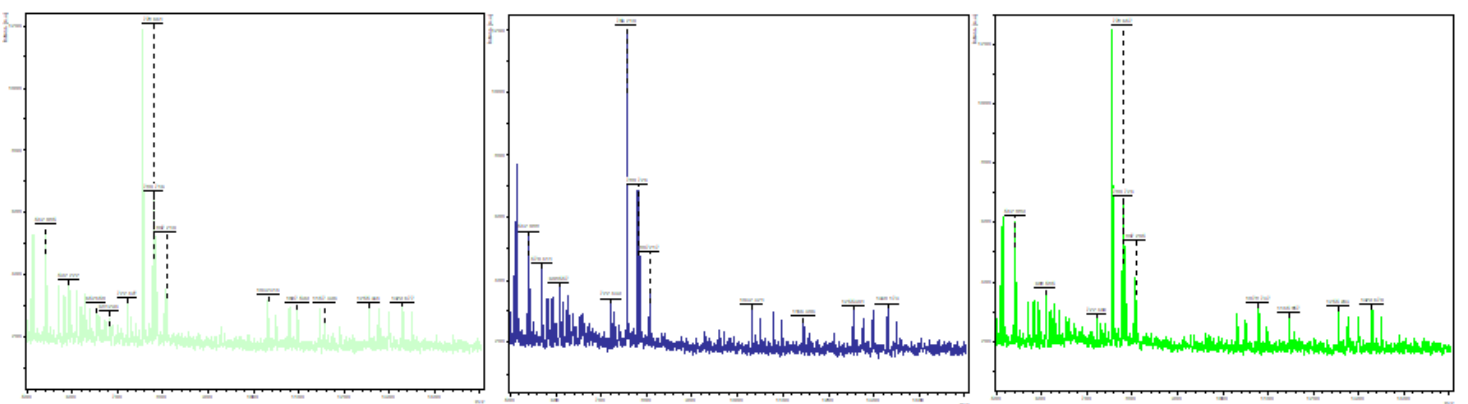
DB ATF 60\% 1.5MI
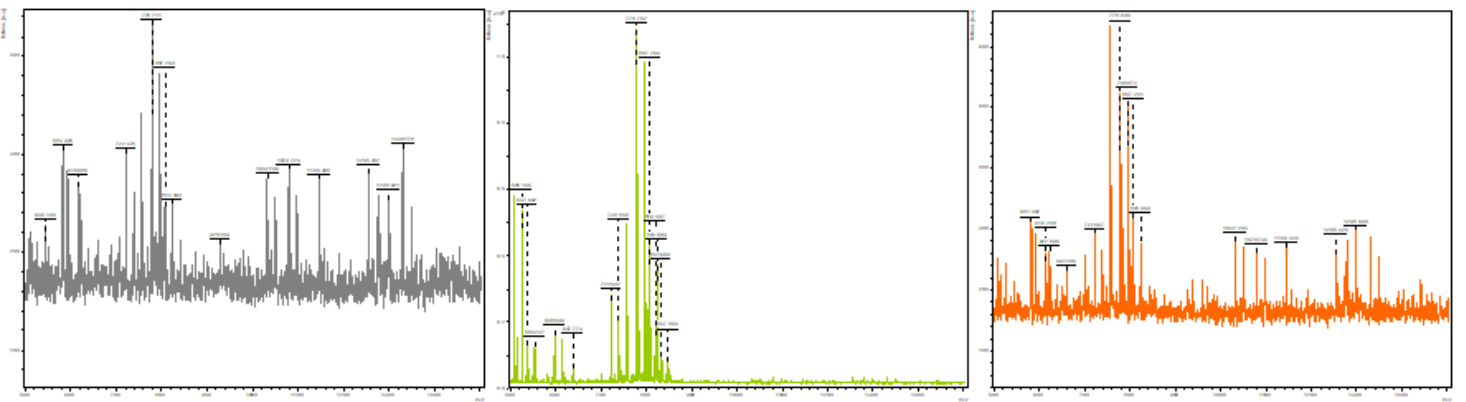

DB ATF 70\% 1.5MI
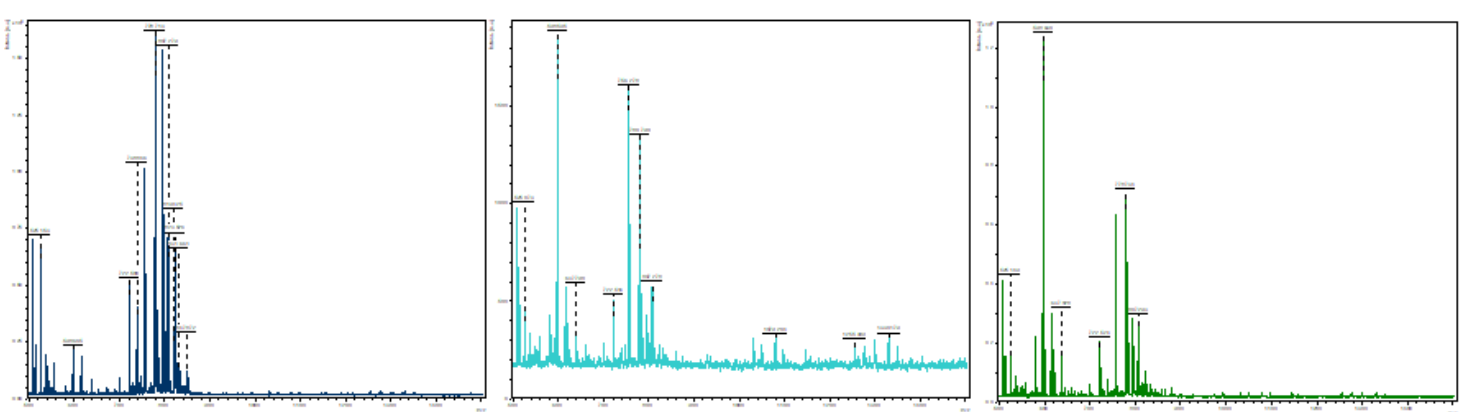

MTBE DHB 60\% 1.5MI
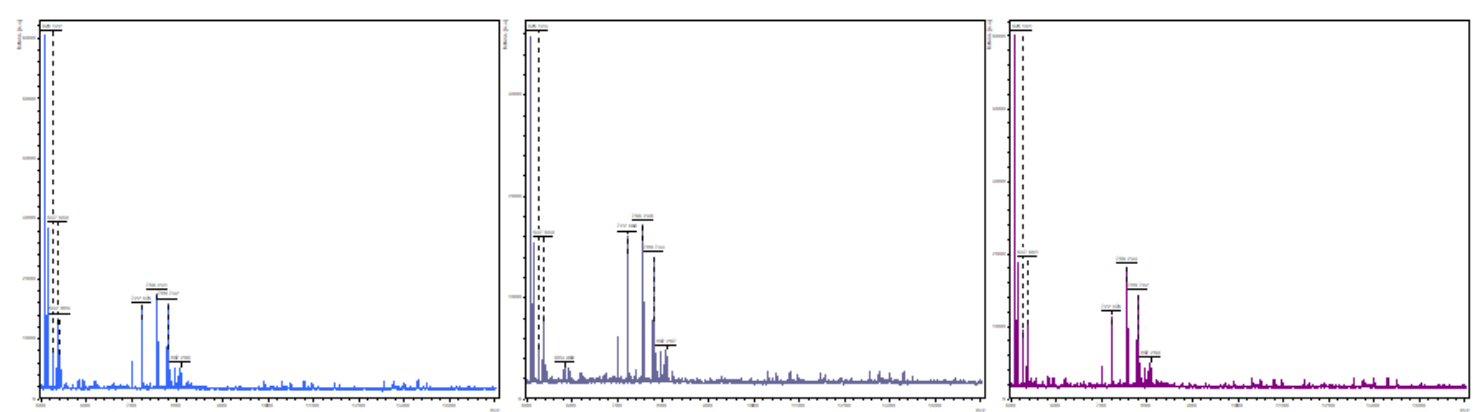

MTBE DHB 70\% 1.5MI
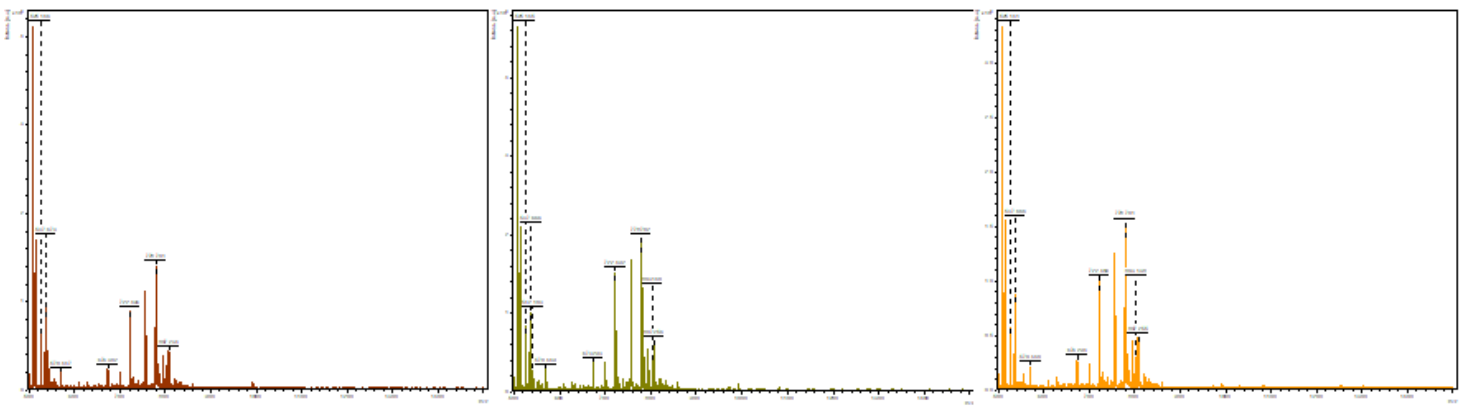

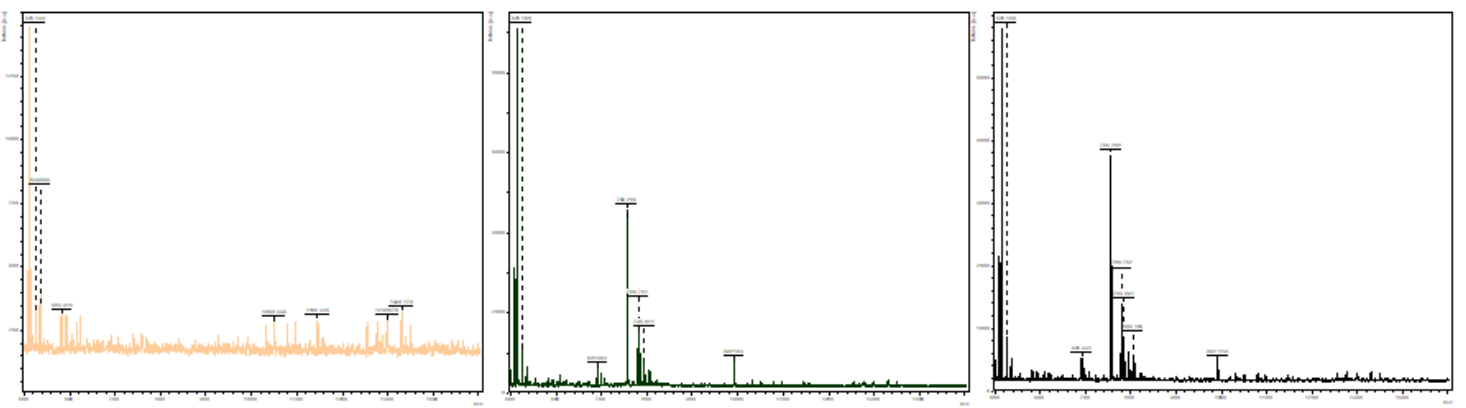

MTBE CIANO 70\% 1.5MI
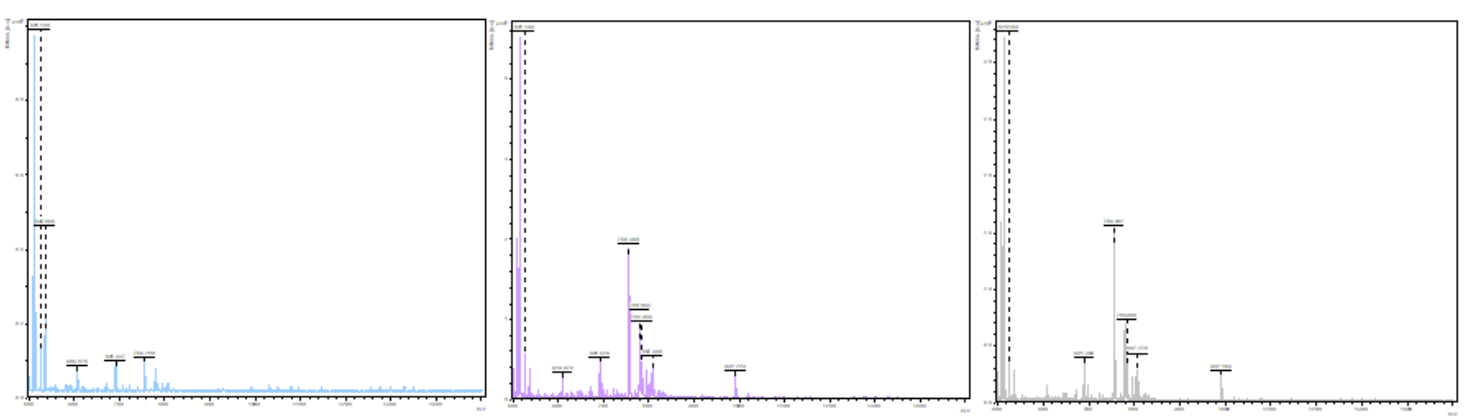

MTBE AMC 60\% $1.5 \mathrm{MI}$
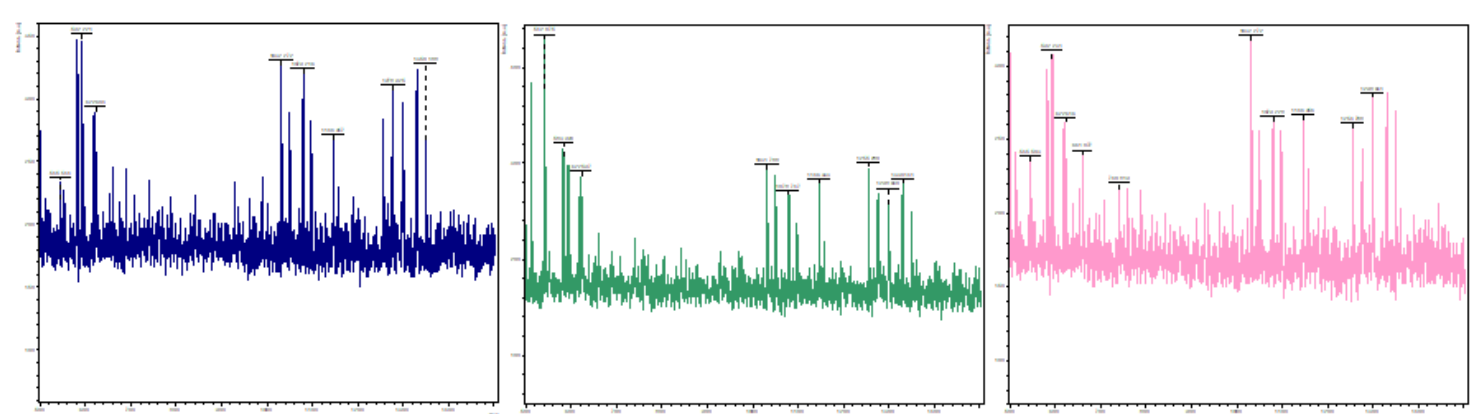

MTBE AMC 70\% 1.5MI
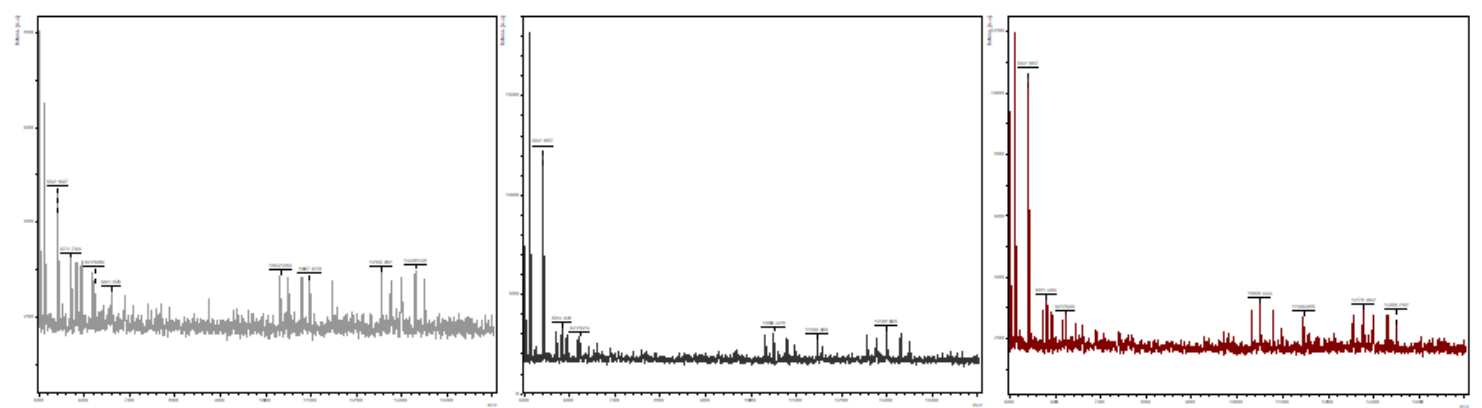
MTBE ATF 60\% 1.5MI
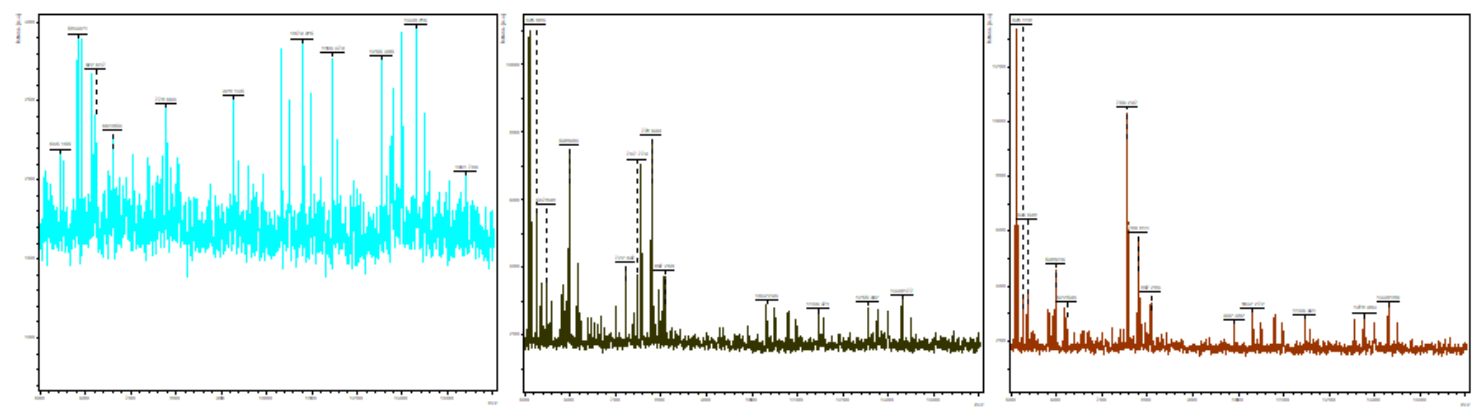

MTBE ATF 70\% 1.5MI
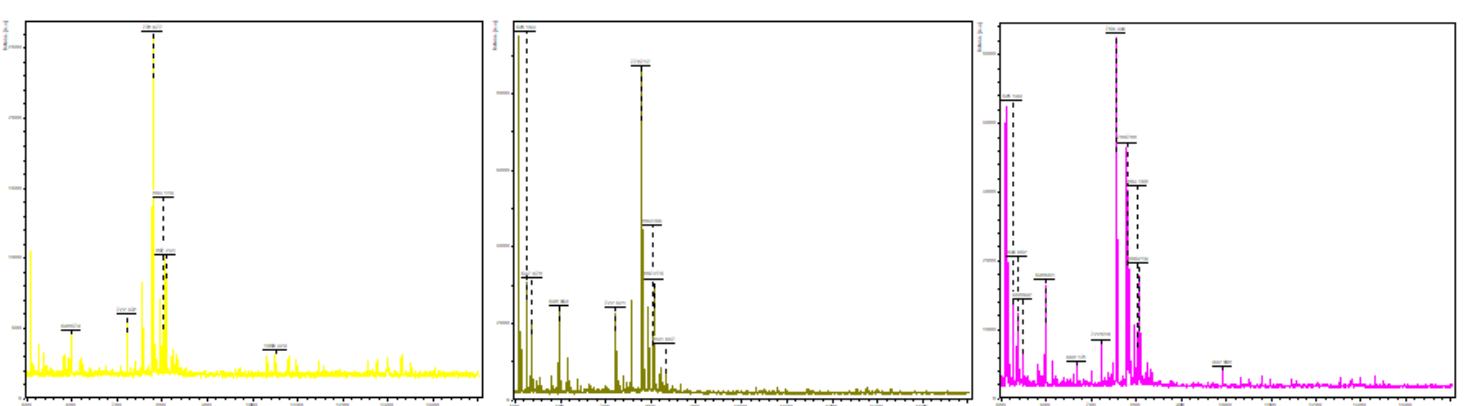